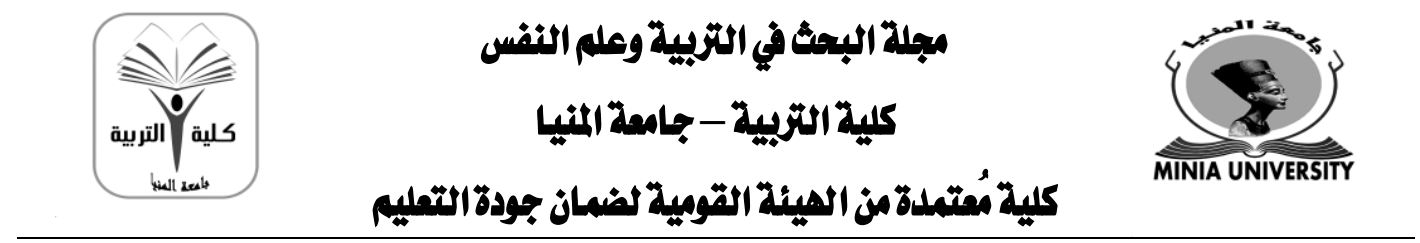

\title{
Using An On-line Digital Tools- Based Program For Fostering EFL Preservice Teachers' Visual Literacy And Seli-appraisal
}

\section{By}

Dalia Ali Maher Abbass Mohammed

A Lecturer of TEFL Methodology, Dept. of Curriculum \& Instruction

\section{Abstract}

Faculty of Education, Minia University

The present study was conducted to investigate the impact of using a program based on online digital tools on fostering EFL pre-service teachers' visual literacy and self-appraisal. The study used the quasiexperimental research method (pre-post control-experimental design). Eighty participants enrolled in the third year, English section at the Faculty of Education were randomly assigned to two intact groups: a treatment group $(n=40)$ and a non- treatment group $(n=40)$. The participants in the treatment group were trained and instructed using a program based on online digital tools whereas their counterparts in the non-treatment group did not receive such training as they received regular instruction. Instruments of the study included a language proficiency test, a needs- analysis survey of $21^{\text {st }}$ teacher competencies, a questionnaire of self-identification, an inventory of visual literacy and a scale of self-appraisal. The findings revealed that the participants in the treatment group significantly surpassed their counterparts in the non-treatment group in the post-performance on the inventory of visual literacy and the scale of self-appraisal.

Key words: Online digital Tools, Visual Literacy, Self-appraisal. 


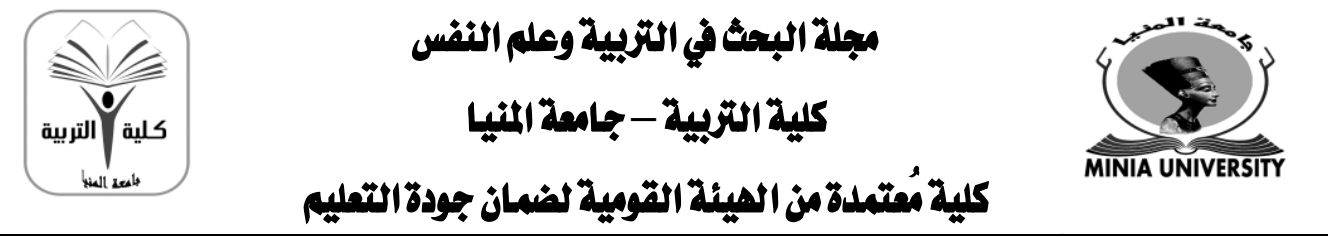

هلضص اللغة العربية:

استفدام برناهج قائم علي الأدوات الرقمية عبر الانتزنت لتعزيز المهرفة البصرية والتقييم الذاتي لدي هملهى اللغة الانبيزية- فى هرحلة ها قبل الفدهة

$$
\text { د/داليا على ماهر مباس معمد الأعداد }
$$

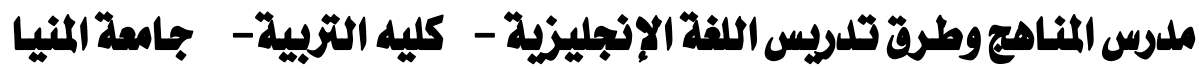

الإستخاص:

تم إجراء الدراسة الحالية للتعرف على اثر استخدام برنامج قائم علي الأدوات الرقمية عبر الانترنت فى تعزيز المعرفة البصرية والتقييم الذاتي للدى معلمي اللفة الانجليزيـة - في مرحلة مـا قبـل الخدمة . ولقد تم استخلام المنهج شبه التجريبى( التصميى القبلى- البعدى ) فى اللدراسة الحالية ـ وقدل اشتملت عينه الدراسة على •^ طالب و طالبه من طلاب الفرقة الثالثة بشعبه اللفة الإنجليزيـة بكلية التربية- جـامعه المنيـا ـ وقد تم تقسيمهيه بشكل عشوائى الى مجموعتين متسـاويتين تامتين إحلداهما

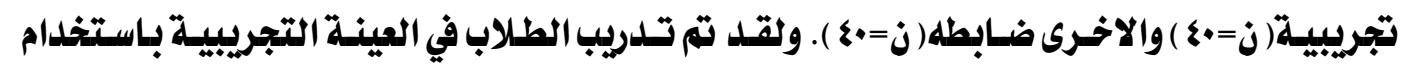
برنامج قائم على الأدوات الرقمية عبر الانترنت من تصميم الباحثة بينما استخدمت الطريقة المعتادة فى إنى التلدريس لطاب العينة الضـابطة. وقد اشتملت أدوات اللدراسة على اختبـار الكفـائة اللفويـة، استبييان لتحليـلد أهم كفائـات معلم القـرن الحسادى و العشرين ، استبييان للتعرف علي الـدات ، مقيساس للمعرفة البصرية ومقياس للتقويم الذاتى. وقد أظهرت النتائج تفوق أداء طلاب العينة التجريبية والدلى يفوق بلدوره أداء طلاب العينة الضابطة فى التطبيق البعلى لمقياس للمعرفة البصرية ومقياس للتقويم الذاتى ـ هذا وقد تم عرض مناقشه و تثسير النتائج والتوصيات والمقتر حات لأبحاث مستقبليه. الكلمات المفتاحية:الأدوات الرقمية عبر الانترنت - المعرفة البصرية - التقويم الذاتى 


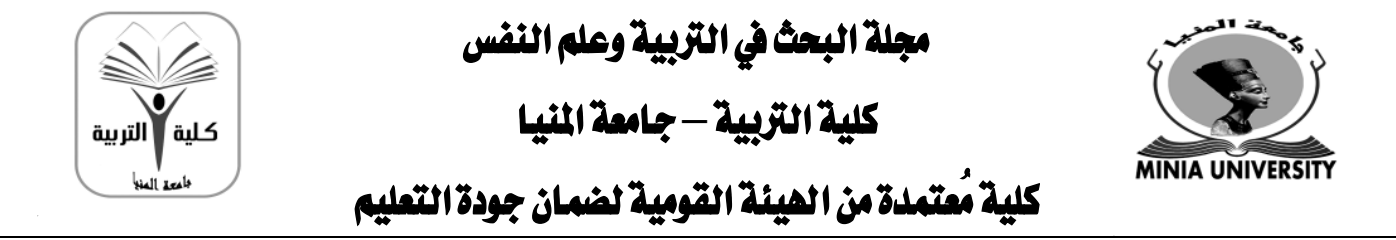

Introduction

Effective education attempts to provide every student the opportunity for a quality education necessary to compete in a global economy. One important factor, among many contributing, is the teacher who serves as a positive role model in the process of preparing life-long learners. So, educators should always work on enhancing their teaching performance. Moreover, every teacher should be provided with the necessary resources, materials, and support to deliver quality instruction in a way that stimulate, motivate and focus learners' attention. Knowledge of computer and other technological skills, referred to as digital literacy, are currently needed by the prospective teachers due to the great developments in online communication. Hence, teachers and teacher educators are obliged to upgrade their ICT knowledge and skills to cope with the 21 st century technology-oriented ways.

The rapid growth of the technology tools that are available to assist with instructional design has resulted from the changing nature of the society and the global marketplace. It may be helpful for instructors to incorporate new technologies into the classroom to add variation to the traditional classroom and to address students as digital natives. This integration of technology in the learning community may lead to greater opportunities for reflection, collaboration and increased learning among learners. Instructors are, therefore, encouraged to reconsider their common teaching and learning theories and the consequences these theories have on the learning outcomes of their learners. Moreover, it's the learners' right to have a learning environment that allow them to develop and explore their creative and linguistic abilities.

The curriculum of the 20th century, as Jansen and Merwe (2015) pinpoint, was subject-based and was mainly directed towards rote learning and memorizing facts, whereas, the modern curriculum should incorporate creatively the new 21 st century skills and competencies that can only be taught through exploration, practice, ○V^

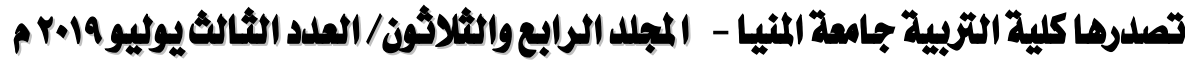 \\ gamel_abdo59@yahoo.com \\ http://ms.minia.edu.eg/edu/journal.aspx}



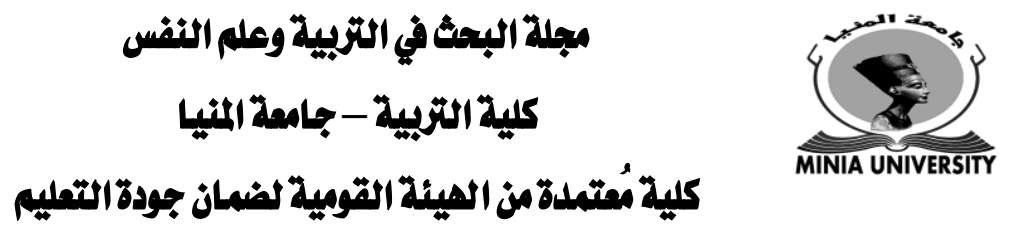

and feedback. Thus, the role of teachers and the systems around them must be reconsidered. Recent research has emphasized the need for instructors to incorporate technological on-line digital tools into the classroom learning environment (Krajka, 2006 ; Pinchot \& Paullet, 2014; Dyer, Larson, Steele \& Holbeck, 2015). These tools can include visual, auditory and textual delivery methods leading to improved student outcomes, motivation and engagement in an interactive and conductive classroom.

In relation to the current emerging learning paradigm, Thomas and Brown (2011, cited in Calvert, 2014:116) point out three important differences between the old and the new one in classrooms. First, the traditional, physical classroom is shifting focus to learning environments that are full of rich sources of information that can be accessed through digital media. Likewise, traditional instruction has directed towards teaching students about the world, whereas the current paradigm guides student learning through engaging with the world. Finally, the traditional teaching culture concentrated on assessment and outcomes while the new culture addresses points of weaknesses and keeps investigating them for better improvement. In addition to the knowledge of digital technology, Sailin and Mahmor (2018) assure that teachers need to develop means of successful technology integration into the classroom.

Hence, providing teachers with various aspects of knowledge through the internet is greatly acknowledged in the current academic arena. Instead of providing the students, especially in higher education institutions, with the needed information in a linear sequential manner, Krajka (2006) and Pohio and Lee (2012) assure the utility of enriching them with a variety of tools and resources to accommodate for creating their own learning resources. Likewise, Zeglen and Rosendale (2018) emphasize the role of educators and course designers in incorporating online technology pedagogically to promote educational delivery (Chinyamurindi \& Dlaza, 2018; Benali, Kaddouri \& Azzimani; 2018) and learners' cognition and information ov 9

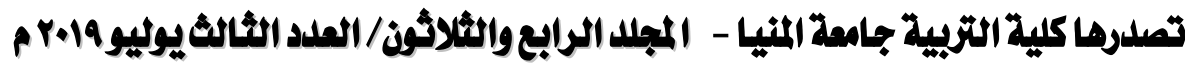 \\ gamel_abdo59@yahoo.com \\ http://ms.minia.edu.eg/edu/journal.aspx}




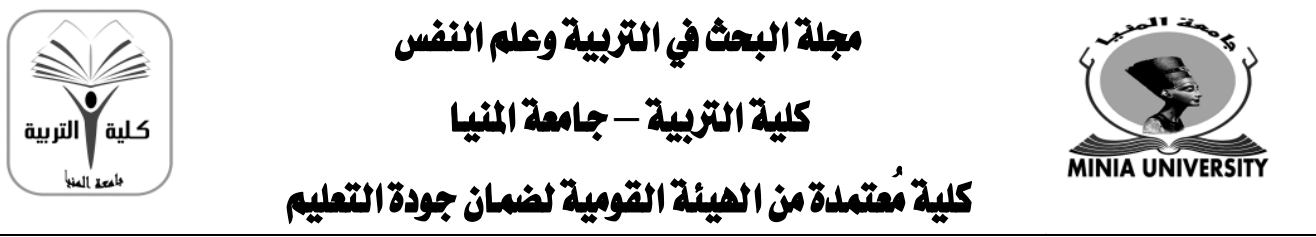

retention (Zeglen \& Rosendale (2018).

\section{Visuals}

Our world today is classified as visual due to the abundance of media and digital stimuli. Among the different elements that teachers can use inside the classroom, visuals play critical role in ensuring the students' comprehension of the presented materials. Visuals enable teachers to present information efficiently as well as students to access information easily regardless of their language proficiency level. Visual tools like photos, info-graphs, real-life objects, and even simple drawings (e.g. stick figures) help learners greatly in assimilating the content being presented in a stimulating environment. Moreover, incorporating images and clipart into definitions, structures and reading passages, according to Shabiralyani, Hasan, Hamad and Iqbal (2015), can increase students' understanding of the written text.

Since we are totally immersed in a visual world, so the teaching of visuals, as argued by Pohio and Lee (2012), should be integrated in the regular daily pedagogy. This is also addressed by Shabiralyani et al. (2015) who have assured the role of visuals in making teaching more effective and enhancing the learning process as well. Moreover, Daniel (2013 cited in Ulloa Salazar and Díaz Larenas, 2018: 95) assure the influence of using audiovisual materials in avoiding excessive, and meaningless verbalization in teaching English, clarifying the presented material using varieties of more effective methods by saving more time and energy.

\section{Visual literacy}

Everything in the world today becomes visual. Since visual imagery has not been considered supplemental to other forms of information, so Hattwig, Burgess, Bussert and Medaille (2011) assure the fact that images and visual media have changed the meaning of being literate in the 21 st century. The availability of new digital tools has enabled everyone to create and share visual media. However, this does not mean that individuals can efficiently use and produce visual content. Hence, Hattwig et al. (2011) emphasize the need to enable

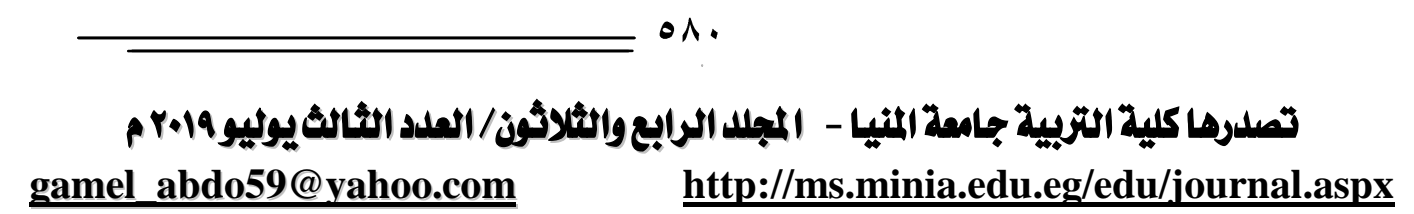



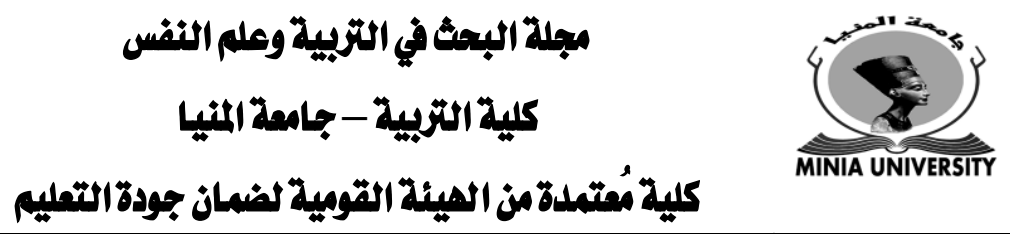

individuals develop the skills essential to engage effectively in a visually-oriented society. Visual literacy, they add, can enable individuals to be actively engaged in a visual culture where a visually literate individual performs the role of critical consumer of visual media as well as an efficient contributor to the available knowledge and culture.

The term of visual literacy, according to Donnchaidh (2017), was first used in 1969 by John Debes, the founder of the International Visual Literacy Association. Like other types of literacy, visual literacy is about language, communication and interaction. The basic definition of visual literacy, as Donnchaidh (2017) indicates, is the ability to read, write and create both static and moving visual images. Visual media, she adds, represents various linguistic tools that can be used to navigate through the surrounding visual digital world. Moreover, advanced visual literates, according to Çam and Kiyici (2017), can interpret everything visual around them; objects, symbols, natural or artificial.

The Visual Literacy Competency Standards (VLCS) for Higher education have articulated some tools for instructors to address visual literacy with university students. VLCS, according to Hattwig et al. (2011), represent an intellectual- structured framework developed in the context of the Information Literacy Competency Standards for Higher Education to be publicly distributed in 2011. VLCS, they add, are designed to enhance the development of the competencies and skills related to the academic use and production of visual media for better professional performance. The implementation of VLCS, which may vary across disciplines, would challenge learners to develop the abilities of visual communication, interpretation and digital media use.

VLCS, as Hattwig et al. (2011) clarify, follow a linear structure. However, they add, learners' information behavior follows an iterative process as they can be involved in searching, interpreting and evaluating at the same time. Consequently, learners may not follow a direct linear progression as they can go forth and back from standard 1

Оᄉ

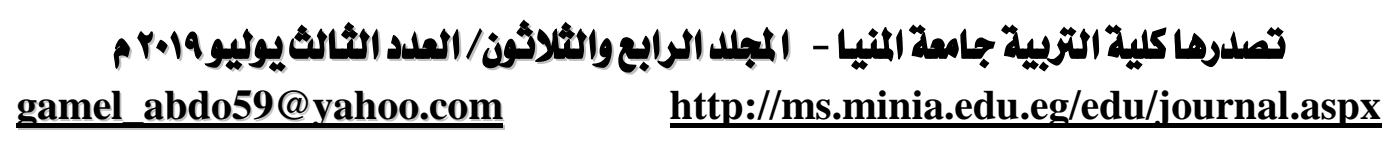



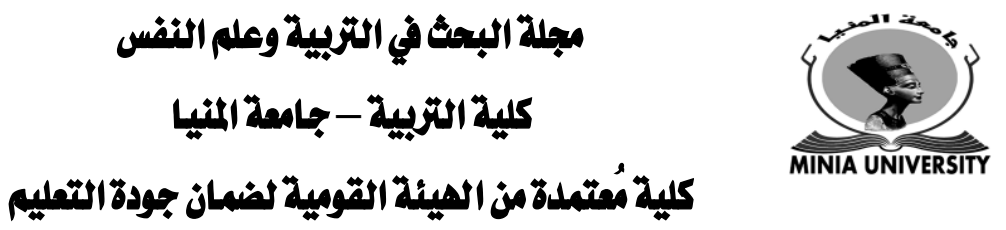

to standard 7. Moreover, finding, accessing and tailoring visual materials according to the different needs of the individuals form the main consideration in visual literacy instruction and the implementation of the VLCS.

\section{The importance of visual literacy}

Since most humans are visually oriented, consequently, research shows the great impact that resulted from improved visual literacy. Visual information is more memorable and easily retained than written or spoken information. Additionally, as Hattwig et al. (2011) indicate, about $90 \%$ of the information that the brain transmits faster is visual in nature. Visuals, they add, increase learners' abilities to mutually absorb meaning underlying texts or other media. Increased visual literacy can also maximize learners' degree of enjoyment. The focus on developing visual literacy, according to Donnchaidh (2017), would increasingly enable learners manipulate their emotions, communicate meaning and to act as informed viewers in the world around them.

Visual literacy, according to Donnchaidh (2017), is not a skill as it uses skills as a toolbox for enhancing learners' mental abilities. Visual literacy is mainly about decoding meaning from different forms of visuals, so, Donnchaidh (2017) assures the importance of teaching the way of approaching visuals through visual literacy clues (VLCs). The categories of VLCs, Hattwig et al. (2011) and Donnchaidh (2017) pinpoint, as subject matter, color, vectors, shapes, etc., represent an approach for examining the details, the stimulated feelings and the underlying intentions of the various aspects of the visuals encountered.

\section{Visual literacy in the classroom}

There are many forms of visual texts that could serve as a starting point for a lesson on visual literacy. Learners are commonly exposed to videos, maps, movies, posters, timelines, diagrams, games, Facebook, Flicker, etc. For training students to become aware visually, teachers need to be, beforehand, well trained. There are three 

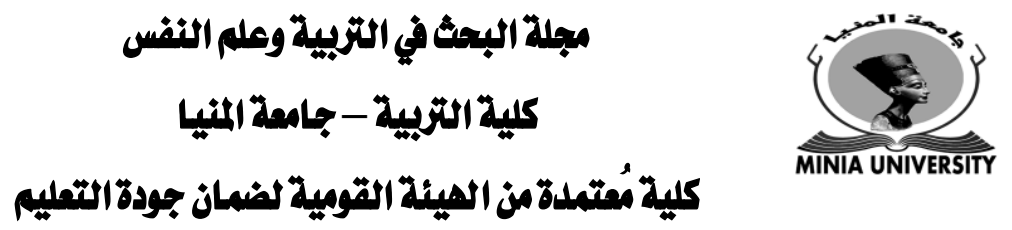

perspectives, according to Keddi (2012), that represent the levels of narrative and language construction of visuals.

1. The objective perspective (the visual and itself), commonly used in the classroom, addresses what can be seen and said about visuals directly by mere looking, e.g. colors, places, actions, etc.

2. The affective perspective (the visual and you) considers the ways thoughts, questions, interpretations, criticism, associations, etc. concerning the used visuals have been verbalized.

3. The contextual perspective (the visual and the world) manages visuals as artefacts (e.g. the underlying theme, the way of their creation, their impact, etc.).

\section{Teacher's self -evaluation}

An increasing global interest in the literature of teacher quality is that teacher evaluation should draw on multiple sources of information, one such source, according to Borg and Edmett (2018), is teacher self-assessment. Teacher self-assessment, they add, is recognized as an option that can enhance teachers' sense of agency and contribute formatively to their subsequent decisions in relation to areas of professional development. Additionally, they indicate the utility of depending on self-assessment tools for providing teachers with a whole picture of their general competencies rather than fragmented classroom observations from external observers.

Due to the various benefits of teacher self- assessment, it has been argued that it should precede all other forms of the evaluation of teaching effectiveness. Pohio and Lee (2012) and Borg and Edmett (2018) enumerate the different forms of methods of self-evaluation of teaching. It can be done through self-monitoring by completing selfevaluation forms after teaching to evaluate the good and the to beimproved aspects of the teaching performance. Another way is through video or audio recordings of teaching or keeping portfolios to keep record of and investigate teaching in detail for later discussions with experts for future improvement. Students' feedback on teaching can form another source of self- evaluation. Keeping on-going 

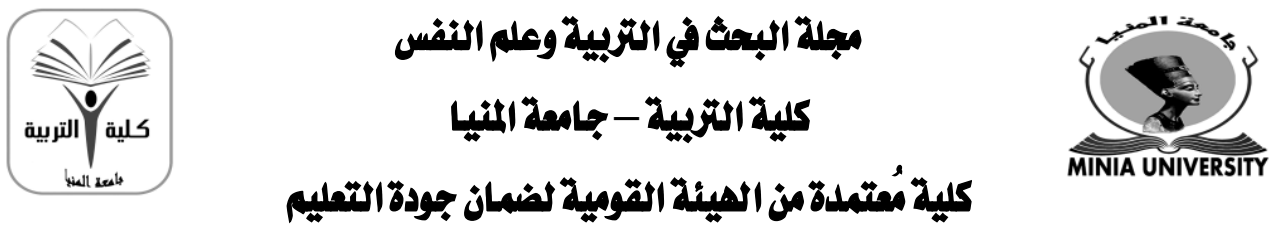

collection of students' ideas and perceptions of the teaching practices provide opportunities for enhancing the teaching practices formatively rather than waiting till the end of the course. Additionally, test results and assignments can be good indicators of how the learning objectives have been achieved.

\section{Online visuals and seli-appraisal}

It is argued that the integration of the online visual materials in the preparation programs of student-teachers could enhance their ability to assimilate the underlying pedagogical meaning (Pohio \& Lee, 2012). Moreover, the practical visual tasks, Pohio and Lee (2012) and Durriyah and Zuhdi (2018) assure, should foster teachers' ownership, increase their reflection skills on their prior knowledge and enable them to reconsider their own future teaching practices. Thus, the integration of visual and textual materials together would convey stronger pedagogical implications.

\section{Digitalization and teacher education}

There is a common agreement, according to Durriyah and Zuhdi (2018), that many student teachers are active users of digital technologies yet they are reluctant to apply digital technologies for teaching purposes. Thus, there is a need to prepare student teachers for technology integration. Additionally needed is knowledge about the way these prospective teachers may integrate digital tools in their actual teaching situations. In teacher education programs, Spires and Bartlett (2012, cited in Durriyah and Zuhdi, 2018) simplify the scope of digital literacy into three categories: finding and using digital content, producing digital content, and disseminating digital content. These categories underlie complex skills and abilities that student teachers must obtain. Skills such as critical thinking and value judgment are very important for selecting and using digital content. Likewise, creativity, innovation, and understanding of socio-cultural context are very critical for producing and disseminating digital content.

From the international perspective, as Benali, Kaddouri and $\bullet \wedge \varepsilon$

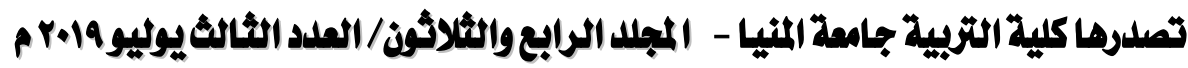

gamel_abd059@yahoo.com

http://ms.minia.edu.eg/edu/journal.aspx 

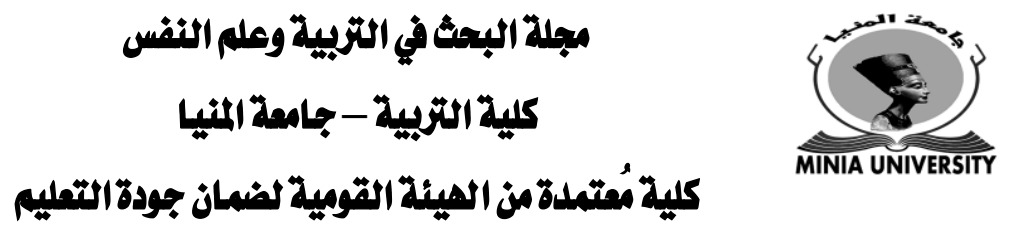

Azzimani (2018) assure, there is an interest in fostering teachers' competences for enhancing teaching and learning and for adequately preparing their students for life and work in a digital society. Teacher training forms a key element for the effective development of students' competences to use technology appropriately and effectively. Lack of training in the effective use of digital tools in a teacher education program will not help student teachers to be prepared for the classrooms of the future. Consequently, there is a need to revise teacher education programs, the pedagogical applications of digital technologies and self-assessment tools to guide teacher training towards the recent standards of professionalism.

\section{Context of the problem}

Language classroom teachers are continuously urged to examine their practices and find new ways of meeting the needs of their new read/write web generation of students. Educators also need to monitor and adjust instruction to increase the learning of all students. Factors such as a lack of adequate time to plan courses, limited technical skills of the computer technologies and the few opportunities available for professional development are common contributors to poor design. However, one of the most significant challenges for teaching staff is the required shift from the way they teach in a traditional lecture-based method to more effective teaching in an online digital learning environment. Likewise, according to Borg and Edmett (2018), it is found that teachers, generally and studentteachers specifically, seem to be not well-prepared in the domain of assessment generally and in self-assessment more specifically

Most schools are under resourced in terms of basic facilities. Additionally, most language teacher education programs, according to Cote, Milliner (2018), do not offer adequate digital training that would enable teachers to create teaching/learning resources for better learning outcomes. Information can be processed through visual and auditory modes. However, Zeglen and Rosendale (2018) assure the importance of delivering information in one channel, whether

O

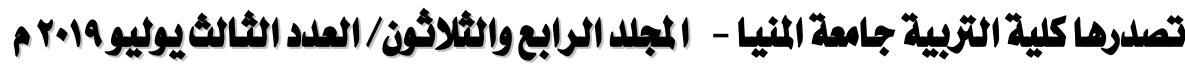 \\ gamel_abd059@yahoo.com \\ http://ms.minia.edu.eg/edu/journal.aspx}



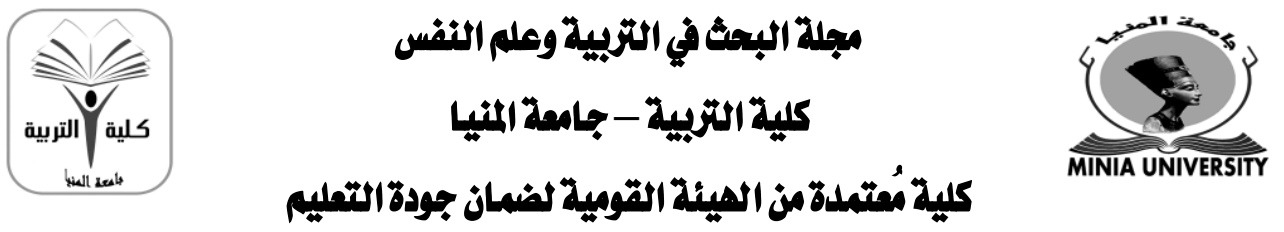

auditory, physical, verbal, or visual, to avoid interference and decrease the cognitive load.

Though the assured impact of adding visuals in the teaching pedagogy (Pohio \& Lee, 2012), creating online visually-based academic materials within institutions is often overlooked for the sake of written materials and textual online resources. Adding visuals, according to (Pohio and Lee, 2012), would be typically for decoration or add-on activities rather than for intentional academic purposes. Likewise, the common trend in training programs usually fosters the how-to skills rather than the underlying meaning. Moreover, according to Hattwig et al. (2011) and Pohio and Lee (2012), scholarly work with images requires analysis, interpretation and evaluation skills closely related to visual materials. However, most teachers, according to Shabiralyani et al. (2015) do not know what and how to make adequate use of visuals. Since all of these aforementioned factors may cause barriers to teaching and learning process, so, these skills need to be taught, trained and integrated into the assigned content.

To be more specific, the researcher submitted a questionnaire of self-identification to the junior students at the English section at the Faculty of Education, Minia University to identify their present experience with online resources and self-evaluation. Concerning their experience with online resources, the majority of them assured the few opportunities they were exposed to online learning experiences and they were rarely being instructed to either use or produce digital resources for teaching situations. Though some of them emphasized their readiness to bring their special teaching resources, the majority affirmed their use of ready- made images or posters from online resources. Concerning their experiences with self-evaluation, though most of the participants assured their desire to be assessed generally and to be self-assessed specifically, they have not received training for self-assessment. Additionally, most of them have known only about exams or quizzes as means of assessment.

$\bullet \wedge 7$

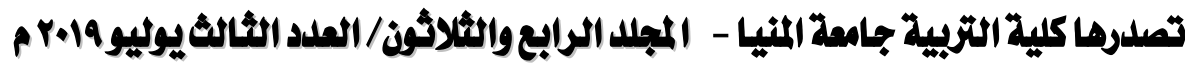 \\ gamel_abdo59@yahoo.com \\ http://ms.minia.edu.eg/edu/journal.aspx}



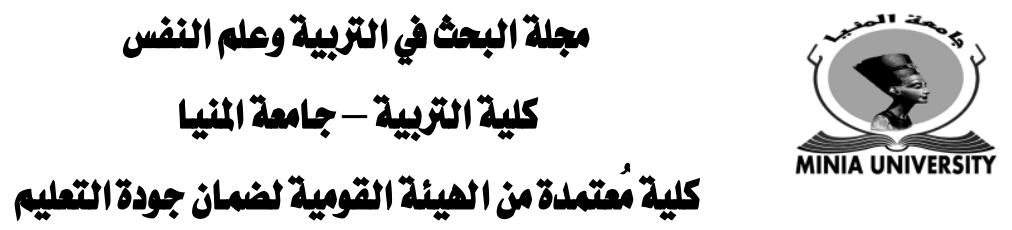

Thus, teaching in the 21 st century demands newly recruited teachers to integrate technology to their classes. More specifically, there is a need for the purposeful selection of visuals that would align with the language teachers' intended learning outcomes. So, the present study attempted to integrate user-friendly online digital tools juxtaposed with face-to-face instruction to enable student-teachers to better process pedagogical knowledge. Moreover, practicing the use of visual tools is sought to improve the student-teachers' visual literacy as well as their self-appraisal.

\section{Review of related literature Theoretical background}

The theoretical approaches guided the present study are represented in the following theories:

- The cognitive theory that supports the integration of text and images to enhance learning (Paivio, 1990 and Sweller, 1994 as cited in Pohio \&Lee, 2012:104).

- The holistic approach that, according to Pohio and Lee ( 2012),draws upon each learner's prior learning and life experiences enabling them to redefine and integrate these experiences in a way that shape their future teaching performance.

- The information processing theory which, according to Zeglen and Rosendale (2018), helps in modeling and predicting the way humans receive, interpret and store information. Moreover, as Riuji (2012, cited in Zeglen and Rosendale, 2018: 25) emphasizes, online teaching resources should only be developed under the guidance of information processing theory integrating effective teaching strategies.

- The frameworks that have emerged to support the use of selfassessment in ELT teacher evaluation. These frameworks, according to Borg and Edmett (2018), are underpinned by the view that, by reflecting in a systematic manner on what they know and can do, teachers can become more aware of the range of competences they need and identify appropriate directions for further development. 


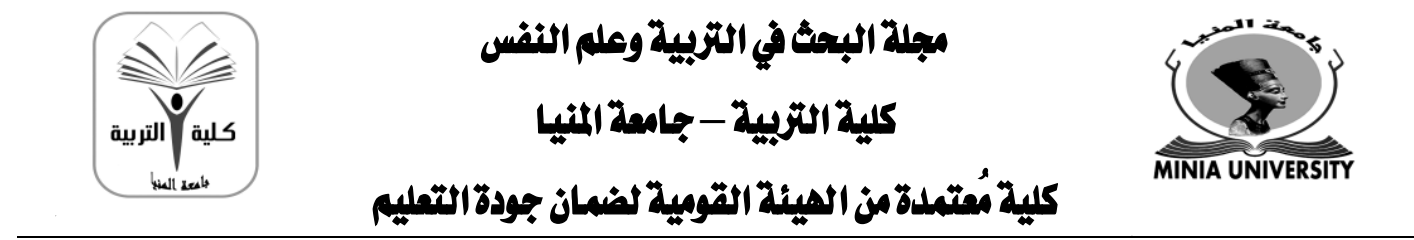

\section{Related studies}

In a systematic review of studies researching the use of online digital tools, the results have shown the great impact of using the online technology in the paradigm of language teaching. This has been shown by Dyer et al. (2015) and Riehemann and Jucks (2017) who have assured that adding on-line technological materials into the classroom would lead to increased students' engagement, motivation and better learning outcomes. Similarly, Thamarana (2017) and Zakareya and Alahmad (2019) have affirmed the utility of internet resources for saving classroom time for applying knowledge and hands-on activities through authentic materials.

Concerning the views of teachers who work on developing their digital literacies, Cote and Milliner (2018) have reported the views of 42 English teachers employed at a private Japanese University in assuring the importance of developing their digital literacies in supporting their classroom practices. In a similar context, after working with 60 student teachers, during their teaching practice in four high schools in Indonesia, Prasojo et al. (2018), have reported the participants' strong belief in the benefit of integrating technology into their teaching performance. Likewise, Sailin and Mahmor (2018) have assured the improvement of both knowledge and skills of 24 final year student teachers from Malaysia in using Web 2.0. which consequently led to their confidence to integrate digital pedagogy in future teaching practices.

Form the learning aspect, Sevcikova (2018) concludes that online open source tools facilitate language learning, helps greatly in improving the quality of writing with the consequent increase in learners' confidence and motivation. Similarly, Ulloa Salazar and Díaz Larenas (2018) have assured the positive change in 18 English as a foreign language young learners' performance regarding their understanding of instructions after being exposed to an audiovisual materials-based teaching strategy. findings show there was a positive change in their performances. 

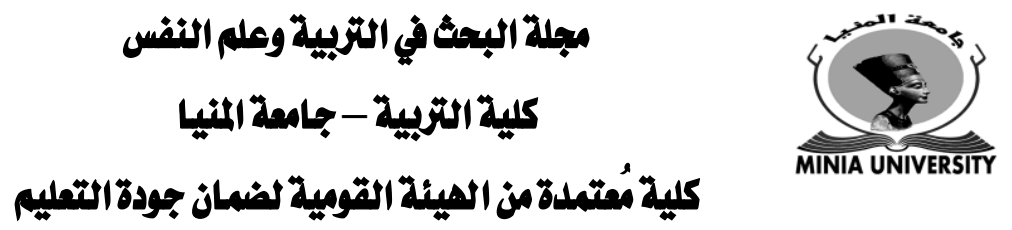

Pedagogically, instructors and course designers should leverage technology to further enhance students' cognition and knowledge retention within the online domain. Zeglen and Rosendale (2018) assure that combining delayed elaborate feedback and visual hints in online courses affect significantly the learners' ability to process information from working memory to long-term memory

Concerning the impact of visuals, Shabiralyani et al. (2015) have assured that the majority of the teachers and students of the public and private educational institutions of District Dera Ghazi Khan had positive perceptions of the use of visual aids (e.g., pictures, animation videos, projectors and films) as a motivational tool in enhancing students' attention in reading literary texts.

While much has been written about teacher self-efficacy and about approaches to professional development such as peer observation and action research which encourage teachers to evaluate their own teaching, limited work, as Borg and Edmett (2018)) assure, is available specifically on teacher self-assessment (Ashraf \& Zolfaghari, 2018 and Stabler-Havener, 2018).

The present study does not assume to bridge the gaps in all the related literature. However, it attempts to shift the focus from the use of online digital tools on developing teachers' general teaching performance to their capacity to maximize their self-appraisal skills. Incorporating face-to-face instruction with focused on-line visual digital teaching strategies would also target the promotion of studentteachers' visual literacy.

\section{Statement of the problem}

Leveraging technology pedagogically to enhance learners' access to academic resources and experiences has become an emerging trend within the regulations of the tertiary institutions and their strategic plans. However, there is a need to ensure that integrating online materials would guarantee quality learning experiences. Similarly, there is a common need to emphasize the personalized nature of instruction while integrating the online

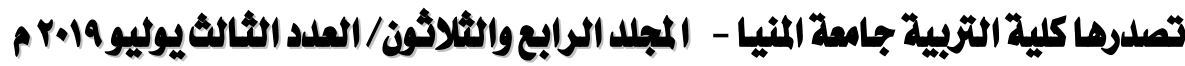 \\ gamel_abdo59@yahoo.com \\ http://ms.minia.edu.eg/edu/journal.aspx}



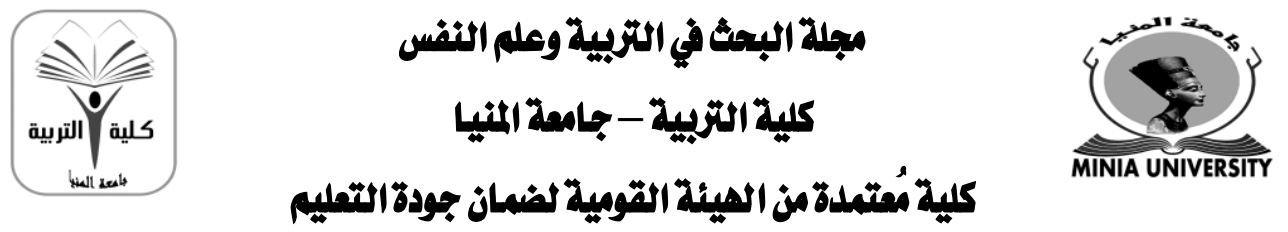

technological applications to develop better learning outcomes. Likewise, students must be equipped to process information in all its forms. More specifically, different types of images whether animated or static seem to prevail our life in this age of internet. Consequently, the need to develop learners' necessary visual literacy to navigate this recent visual-intense world becomes urgent.

In general, the teaching profession is facing regular challenges and demands, which require a new vision and more sophisticated set of competences than before. Since the teaching practice is the first starting activity implemented to train student-teachers in professional teaching practice, so they need to be trained adequately from the early beginning to establish their habits and professional perceptions. Integrating meaningful, content-supported online digital tools within the domain of teaching strategies is thought to enhance studentteachers' pedagogy, provide more flexible interaction, increase overall teaching performance and, more specifically, maximize their visual literacy and their self-assessment.

\section{Questions of the study}

The present study attempted to answer the following questions:

1. What is the effect of using an online digital tools-based program on fostering EFL pre-service teachers' visual literacy?

2. What is the effect of using an online digital tools-based program on fostering EFL pre-service teachers' self-appraisal?

\section{Purposes of the study}

The current study attempted to identify:

1. the effect of using an online digital tools-based program on fostering EFL pre-service teachers' visual literacy.

2. the effect of using an online digital tools-based program on fostering EFL pre-service teachers' self-appraisal.

\section{Hypotheses of the study}

The present study attempted to test the following hypotheses:

1. There would be a statistically significant difference between mean values obtained by the participants of the treatment and the non09.

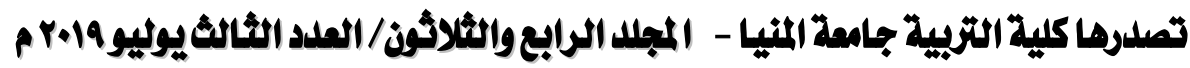

gamel_abd059@yahoo.com

http://ms.minia.edu.eg/edu/journal.aspx 

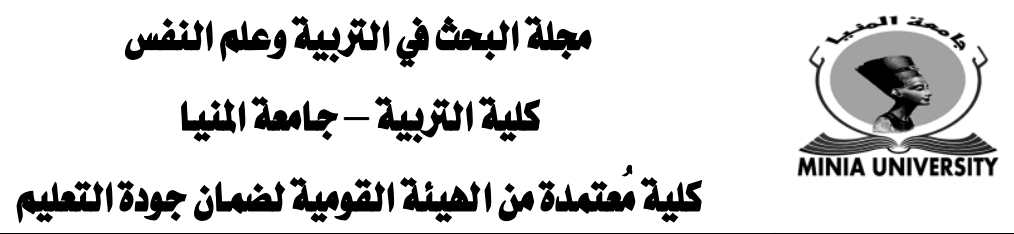

treatment groups on the post- performance on the inventory of visual literacy (favoring the treatment group).

2. There would be a statistically significant difference between mean values obtained by the participants of the treatment and the nontreatment groups on the post- performance on the scale of selfappraisal (favoring the treatment group).

\section{Significance of the Study}

The use of online digital tools-based program in the tertiary level in relation to the context of teaching in the present study is hopefully expected to:

- minimize the gap between how technology is applied in classroom teaching and the opportunities offered by technology to enhance student learning.

- ensure that student- teachers online- digital and connected professional teaching strategies are of high quality, consistent with the standards for teaching and leading in the digital age, and would likely lead to improve their teaching practice, their digital literacies and their student learning.

- empower student-teachers with the abilities of visual communication, critical analysis and interpretation through actively engaged in online visual digital tools. Additionally, their awareness about the ethical values of using visuals would be raised and fostered.

- enable student-teachers to become better self-assessors and thus to become better teachers.

- enable educators to use social media in instructionally sound ways that maximize learning. Moreover, they would be equipped with ideas, teaching strategies and activities for using current and effective online digital tools to support their teaching. Additionally, through these online digital tools, educators can promote their learners' cognition, problem solving, critical and creative thinking skills.

- enable curriculum designers to better design and develop digital- 

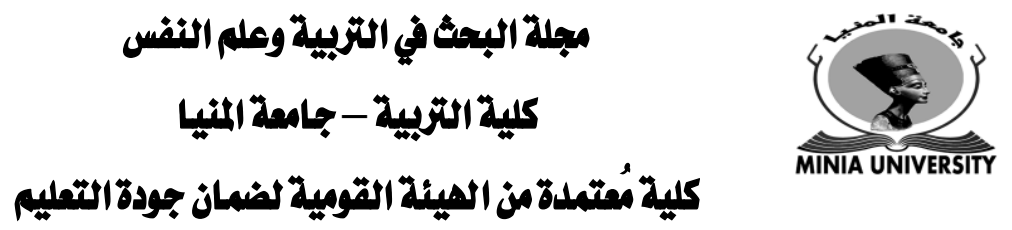

age learning experiences and assessments to promote and model digital citizenship and responsibility, develop better opportunities for all students' success and engage educators in systematic improvement, professional growth and leadership.

\section{Delimitations of the study}

The present study was delimited to the following elements:

1- The participants are third- year English majors, juniors, enrolled at the Faculty of Education, Minia University, in the second semester of the academic year 2018/2019.

2- The visual type of on-line digital tools is the only one used in the present study.

3- The nature, sources, types, organization, design and interpretation of visuals have been the standards of visual literacy that are only incorporated in the present study.

4- Self-appraisal is only measured in relation to the aspect of language teaching performance.

5- General professional skills of language teaching, instructional delivery and language teaching skills are the only dimensions measured in relation to self-appraisal.

\section{Definitions of terms}

\section{on-line digital tools}

- Operationally, it is defined in the present study as the tools, which by sight, can make learning experiences more real, enjoyable, active and accurate.

\section{Visual literacy}

- Donnchaidh (2017) defined it as the ability to read, write and create static and moving visual images.

- Çam and Kiyici (2017: 30) defined it as the formation, adaptation, usage and interpretation of pictures and videos using the new and the traditional media to improve thinking, deciding, communicating and learning processes

- Operationally, it is defined in the present study as the abilities to create and interpret visual images and tools for purposes of 


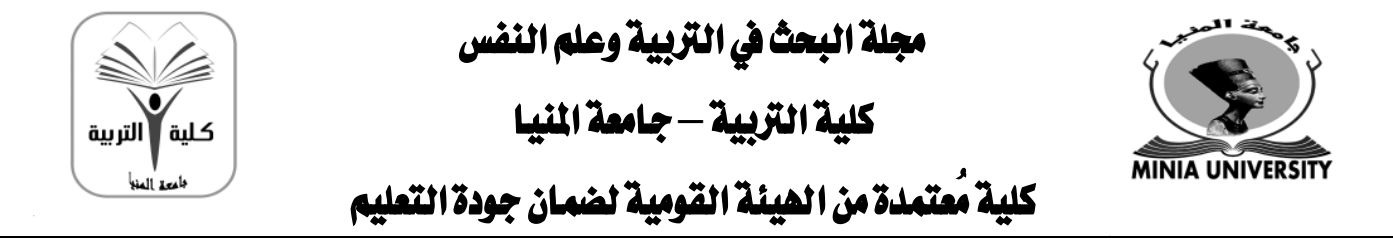

communication, exchanging ideas and interaction.

\section{Seli-appraisal}

- Andrade and Du (2007, cited in Spiller, 2012:3) defined it as a process of formative assessment during which students/ teachers reflect on and evaluate the quality of their work and their learning, judge the degree to which they reflect explicitly stated goals or criteria, identify strengths and weaknesses in their work and revise accordingly.

- Operationally, it is defined in this study as the teacher's ability to create and use assessment practices in order to trace personal development.

\section{Method}

\section{Design of the study}

The present study utilized the quasi-experimental research design. The pre-post control group design (Hatch and Farhady, 1982) was used in designing and conducting the study. A treatment group and a non - treatment group were exposed to pre and post means of getting data. The treatment group only was instructed and trained using a program-based on online digital tools while the non-treatment group did not receive such training.

\section{Participants of the Study}

The main sample of the study consisted of eighty (80) English majors enrolled in the third year at the Faculty of Education, Minia University in the academic year 2018/2019. They were randomly divided into two equal intact groups; treatment and non-treatment and were of the same age level and the same grade level. Homogeneity was established between participants in both groups at the entry level before the intervention as follows:

Age. The two groups of the study were matched on age as the age level of all the participants ranged from 20.5: 22 years old with nearly the same number in each group. Table (1) shows no significant difference between the participants in both groups as the $(t)$ value (1.247) is not significant at 0.05 level

$$
\text { oqr }
$$

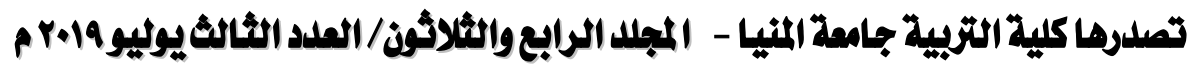

gamel_abdo59@yahoo.com

http://ms.minia.edu.eg/edu/journal.aspx 


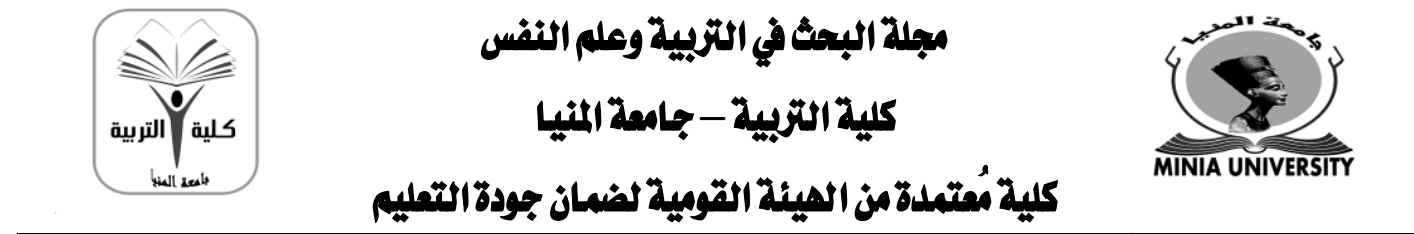

Table (1)

Means, Standard Deviation and t-value of participants' age

\begin{tabular}{ccccccc}
\hline Group & Subjects & Means & SD & t-value & df & Sig. (2-tailed) \\
\hline Treatment & 40 & 20.950 & 0.4206 & -1.247 & 78 & 0.216 \\
Non-treatment & 40 & 21.075 & 0.4743 & & & \\
\hline
\end{tabular}

Note. *. Not significant at 0.05 level

Level of language proficiency. The two groups of the study were matched on their level of language proficiency. Table (2) shows no significant difference between the participants in both groups as the (t) value $(0.600)$ is not significant at 0.05 level.

Table (2)

Means, Standard Deviation and t-value of participants' language proficiency

\begin{tabular}{ccccccc}
\hline Group & Subjects & Means & SD & t-value & df & Sig. (2-tailed) \\
\hline Treatment & 40 & 12.60 & 1.355 & -0.600 & 78 & 0.550 \\
Non-treatment & 40 & 12.78 & 1.250 & & & \\
\hline Note. ${ }^{*}$. Not significant at & 0.05 level & & & &
\end{tabular}

Linguistic background. All the participants studied English for 12 years (from primary (1) till the end of the secondary stage) at public schools in Minia Governorate. In addition to another 2 years at their university level till they became juniors.

\section{Variables of the Study}

The independent variable. The use of online digital tools- based program.

The dependent variables. They include the level of visual literacy and the level of self-appraisal.

Instruments of the study

1- A needs- analysis survey of $21^{\text {st }}$ teacher competencies

$21^{\text {st }}$ teacher competencies had been listed after reviewing the related literature and was administered to jury members to select the most important and relevant competencies to be used as the basis for training the treatment group of the present study.

2- A questionnaire of self-identification.

Purposes of the questionnaire. Identifying the background knowledge and experiences that the EFL junior students have 

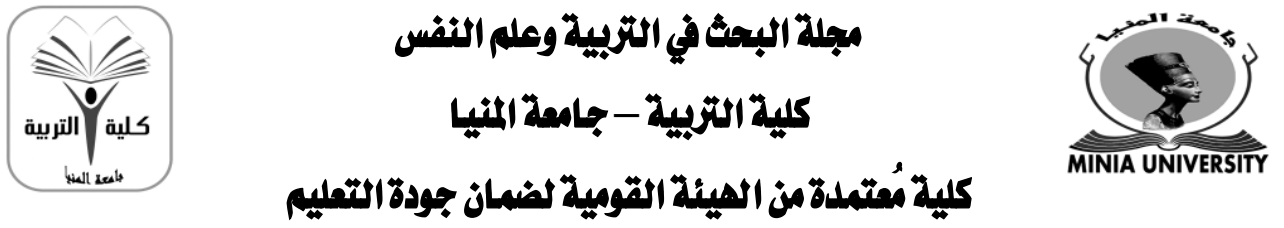

concerning their online experiences. It also helps in figuring out the participants' relevant experience of self-appraisal of their teaching performance.

Construction of the questionnaire. a- Reviewing the literature related to the domain of online digital tools. b- Stating the objectives of the questionnaire. c- Designing a preliminary questionnaire. It consists of two variables with 11 multiple-choice items. d- Evaluating the preliminary form of the questionnaire by a jury of 5 TEFL experts.

Validity of the questionnaire. A jury of 5 TEFL experts approved the face validity of the questionnaire, its suitability and appropriacy for the study sample.

Administration of the questionnaire. The questionnaire was administered to EFL junior students to determine their background knowledge and experience concerning online experience and selfappraisal in relation to the teaching context.

Results. Analyzing the data obtained revealed the scarce opportunities that the majority of the participants had in relation to online teaching or learning experiences. Moreover, the majority assured their readiness to prepare their special teaching resources. Though they indicated that they did not use or were trained to produce any digital tools to be applied for teaching purposes. Concerning their experience with self-appraisal, most of the participants assured their desire to be assessed and be involved in self-assessment. However, they clarified that they were not trained in assessment practices, or become acquainted with the different types of assessment tools. Table (3) presents the percentage of the participants' choice of the items of the questionnaire. 


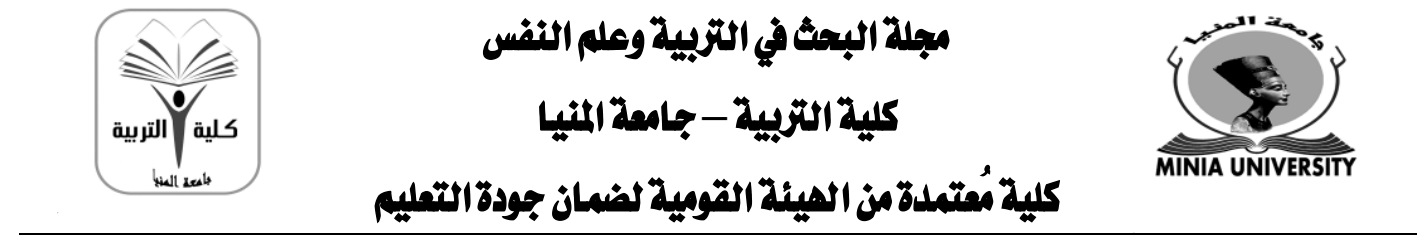

Table (3)

Analysis of questionnaire

\begin{tabular}{|c|c|c|c|c|}
\hline The Variable & $\begin{array}{c}\text { Corresponding } \\
\text { number of } \\
\text { statements }\end{array}$ & $\begin{array}{r}\text { Variable/ } \\
\text { distril }\end{array}$ & onse & $\begin{array}{c}\text { Total } \\
\text { number } \\
(\mathbf{N})\end{array}$ \\
\hline \multirow{10}{*}{$\begin{array}{c}\text { Online } \\
\text { experiences }\end{array}$} & \multirow{2}{*}{1} & Few & $90 \%$ & \multirow{21}{*}{40} \\
\hline & & Sometimes & $10 \%$ & \\
\hline & \multirow{2}{*}{2} & Few & $50 \%$ & \\
\hline & & Sometimes & $50 \%$ & \\
\hline & \multirow{2}{*}{3} & Few & $90 \%$ & \\
\hline & & Sometimes & $10 \%$ & \\
\hline & \multirow{2}{*}{4} & Few & $90 \%$ & \\
\hline & & Sometimes & $10 \%$ & \\
\hline & \multirow{2}{*}{5} & $\begin{array}{l}\text { Ready-made } \\
\text { charts }\end{array}$ & $10 \%$ & \\
\hline & & Photos & $90 \%$ & \\
\hline \multirow{11}{*}{ Self-evaluation } & \multirow[b]{2}{*}{6} & Few & $90 \%$ & \\
\hline & & Sometimes & $10 \%$ & \\
\hline & 7 & Few & $100 \%$ & \\
\hline & \multirow{2}{*}{8} & Sometimes & $20 \%$ & \\
\hline & & Always & $80 \%$ & \\
\hline & \multirow{2}{*}{9} & Few & $20 \%$ & \\
\hline & & Sometimes & $80 \%$ & \\
\hline & \multirow{2}{*}{10} & Few & $80 \%$ & \\
\hline & & Sometimes & $20 \%$ & \\
\hline & \multirow{2}{*}{11} & Tests & $50 \%$ & \\
\hline & & Quizzes & $50 \%$ & \\
\hline
\end{tabular}

\section{3- An inventory of visual literacy}

Purpose of the inventory. An inventory of visual literacy was designed by the researcher for EFL pre-service teachers (juniors) to identify their ability levels in relation to the standards of visual literacy and measure the degree of improvement of the participants in both groups on their abilities in handling visual materials after finishing the course.

Construction of the inventory. It is constructed on the basis of a 097

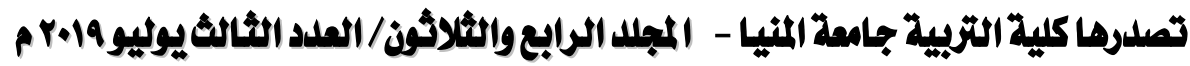

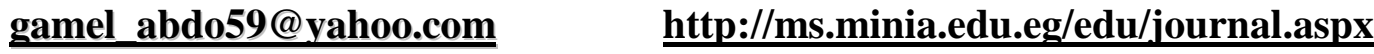



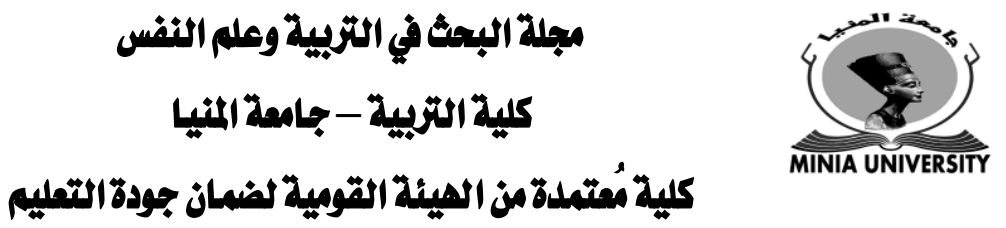

three-point Likert-type scale. The most important and relevant standards of visual literacy are classified and represented in the inventory through a group of 5 dimensions, each followed by a group of statements that are developed for measuring the participants' level of visual literacy after being involved in an online digital tools-based program with the total number of 32 statements. Each statement has three response categories rating as follows: poor, developing and professional. Responses are given scores (weights) according the scale response categories as follows: poor (1), developing (2) and professional (3). Maximum score on the scale is 96. This is shown in table (4).

Table (4)

The Dimensions An inventory of Visual Literacy

\begin{tabular}{ccc}
\hline No. & Dimensions of the inventory & No. of items \\
\hline 1 & $\begin{array}{c}\text { The nature of the visual materials needed } \\
\text { The sources and types of the visual } \\
\text { materials }\end{array}$ & 6 \\
3 & $\begin{array}{c}\text { The effective search and organization for } \\
\text { visuals }\end{array}$ & 8 \\
4 & $\begin{array}{c}\text { The creation and design of visuals } \\
5\end{array}$ & 6
\end{tabular}

Total number of items

32

Total score

96

Instructions of the inventory. They are written in English. They are easy to understand. They include information about the purpose of the inventory, its dimensions, the distribution of the scores on the points of the scale of the inventory and the way of recording the answer.

Piloting the inventory. Piloting the inventory was done with a group of forty (40) male and female EFL pre-service teachers (juniors) enrolled at the Faculty of Education, Minia University in the academic year 2018/2019. Those participants were excluded later on from the intervention. Time taken by each participant was recorded, divided by the whole number of participants who took the inventory and was

$\bullet 9 V$

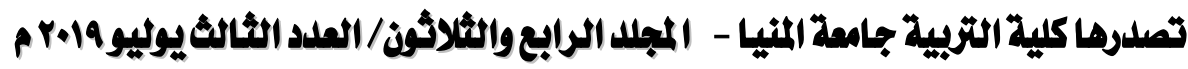

gamel_abd059@yahoo.com

http://ms.minia.edu.eg/edu/journal.aspx 

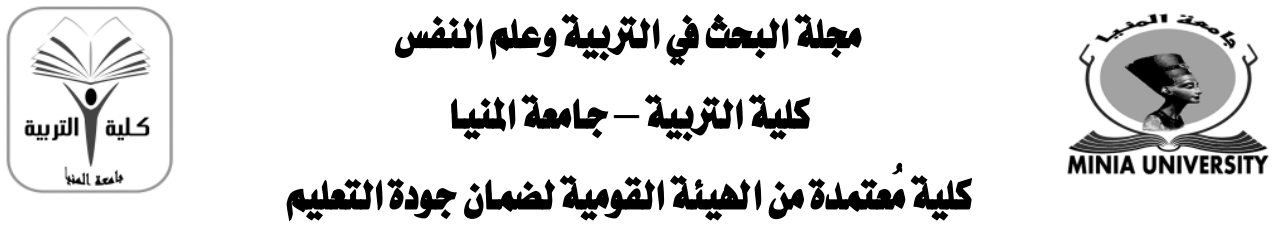

found to be 45 minutes. Thus, the allotted time for using the inventory was 45 minutes.

\section{Validity of the inventory.}

1- The face validity of the inventory. It was determined by submitting it to a jury of 5 TEFL experts to judge its validity according to the following criteria: linguistic stating of statements, relatedness of the statements to the standards of visual literacy and suitability of the statements to the subjects. The suggestions and recommendations of the jury members were taken into consideration and the inventory was revised to reach its final form.

2- Pearson correlation. It was used to determine the internal consistency of the inventory. The same piloting sample (40 EFL junior students) took the inventory. The internal consistency of each statement was calculated. The internal consistency of the individual statements of the dimensions of the inventory was calculated as shown in table (5). The correlation between the five dimensions of the inventory and the total inventory was determined as shown in table (6). The values of the correlation coefficient, ranged from (0.360: 0.973), are considered acceptable.

Table (5) The Internal Consistency of the Inventory of Visual Literacy

\begin{tabular}{|c|c|c|c|c|c|}
\hline Item no. & $\begin{array}{c}\text { Internal } \\
\text { consistency }\end{array}$ & Item no. & $\begin{array}{c}\text { Internal } \\
\text { consistency }\end{array}$ & Item no. & $\begin{array}{c}\text { Internal } \\
\text { consistency }\end{array}$ \\
\hline A1 & $.565 * *$ & $\mathrm{C} 1$ & $.602 * *$ & D4 & $.724 * *$ \\
\hline $\mathrm{A} 2$ & $.825 * *$ & $\mathrm{C} 2$ & $.394 *$ & D5 & $.593 * *$ \\
\hline A3 & $.944 * *$ & $\mathrm{C} 3$ & $.693 * *$ & D6 & $.704 * *$ \\
\hline A4 & $.742 * *$ & $\mathrm{C} 4$ & $.432 * *$ & E1 & $.800 * *$ \\
\hline A5 & $.824 * *$ & $\mathrm{C} 5$ & $.530 * *$ & E2 & $.838 * *$ \\
\hline A6 & $.565^{* *}$ & C6 & $.915 * *$ & E3 & $.568 * *$ \\
\hline B1 & $.973 * *$ & $\mathrm{C} 7$ & $.840 * *$ & $\mathrm{E} 4$ & $.648 * *$ \\
\hline B2 & $.973 * *$ & $\mathrm{C} 8$ & $.545 * *$ & E5 & $.684 * *$ \\
\hline B3 & $.360 *$ & D1 & $.920 * *$ & E6 & $.699 * *$ \\
\hline B4 & $.516 * *$ & D2 & $.815 * *$ & E7 & $.510^{* *}$ \\
\hline B5 & $.360 *$ & D3 & $.828 * *$ & - & - \\
\hline
\end{tabular}

Note. $* *$. Correlation is significant at the 0.01 level (2-tailed).

Note. *. Correlation is significant at the 0.05 level (2-tailed). 


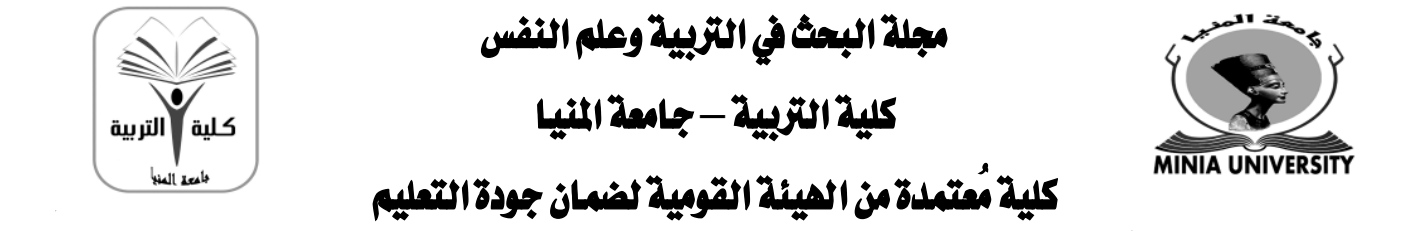

Table (6)

The Correlation Between Each Dimension and The Total Inventory

Dimensions Internal consistency

The nature of the visual materials needed $.800 * *$

The sources and types of the visual materials $.738 * *$

The effective search and organization for visuals $.822 * *$

The creation and design of visuals $.557 * *$

The interpretation and analysis of visuals $.785^{* *}$

Note. **. Correlation is significant at the 0.01 level (2-tailed).

Reliability of the inventory. Establishing the reliability of the inventory was done during piloting. The same piloting sample (40 EFL junior students) took the inventory. The reliability coefficient of the inventory was determined using:

1- Alpha Cronbach $(\alpha)$ coefficient. It is (0.914). It is considered acceptable as shown in table (7)

Table (7)

The Cronbach Alpha's Reliability coefficient of the scale

\begin{tabular}{|c|c|c|c|c|c|}
\hline Dimensions & Means & Variance & $\begin{array}{c}\text { Standard } \\
\text { Deviation }\end{array}$ & $\begin{array}{l}\text { No. of } \\
\text { items }\end{array}$ & Alpha \\
\hline $\begin{array}{l}\text { The nature of the visual } \\
\text { materials needed }\end{array}$ & 7.38 & 3.420 & 1.849 & 6 & 0.849 \\
\hline $\begin{array}{c}\text { The sources and types of } \\
\text { the visual materials }\end{array}$ & 5.60 & 1.169 & 1.081 & 5 & 0.733 \\
\hline $\begin{array}{l}\text { The effective search and } \\
\text { organization for visuals }\end{array}$ & 9.13 & 2.881 & 1.697 & 8 & 0.793 \\
\hline $\begin{array}{c}\text { The creation and design } \\
\text { of visuals }\end{array}$ & 6.33 & 1.097 & 1.047 & 6 & 0.857 \\
\hline $\begin{array}{l}\text { The interpretation and } \\
\text { analysis of visuals }\end{array}$ & 8.08 & 2.738 & 1.655 & 7 & 0.806 \\
\hline Total of dimensions & 36.50 & 30.872 & 5.556 & 32 & 0.914 \\
\hline
\end{tabular}

2- The split-half method. Guttman split-half Coefficient of the inventory is 0.704 . It is considered acceptable as shown in table(8) 


\begin{tabular}{|c|c|c|c|c|c|}
\hline \multicolumn{6}{|c|}{$\begin{array}{l}\text { Table (8) } \\
\text { The Split-half Reliability coefficient of }\end{array}$} \\
\hline $\begin{array}{l}\text { The inventory of } \\
\text { visual literacy }\end{array}$ & Means & Variance & $\begin{array}{l}\text { Standard } \\
\text { Deviation }\end{array}$ & $\begin{array}{l}\text { No. of } \\
\text { items }\end{array}$ & $\begin{array}{l}\text { Guttman split- } \\
\text { half coefficient }\end{array}$ \\
\hline Part 1 & 18.35 & 9.926 & 3.150 & $16 a$ & \\
\hline Part 2 & 18.15 & 10.079 & 3.175 & $16 b$ & 0.704 \\
\hline Both Parts & 36.50 & 30.872 & 5.556 & 32 & \\
\hline
\end{tabular}

Note. ${ }^{*}$ Correlation is significant at the 0.05 level (2-tailed).

Cohen et al. (2007:530) point out that the reliability coefficients are considered reliable if they range from 0.50 to 0.90 . Thus, the reliability coefficients of the inventory are considered within the acceptable range.

\section{4-A Scale of Seli-appraisal}

Purpose of the scale. A scale of self-appraisal was designed by the researcher for EFL pre-service teachers (juniors) to identify their ability levels to evaluate themselves in relation to some dimensions of teaching performance and measure the degree of improvement of the participants in both groups on their abilities to self-assess their teaching performance after finishing the course.

Construction of the scale. It is constructed on the basis of a three-point Likert-type scale. The most important and relevant skills of language teaching performance are classified and represented in the scale through a group of 3 dimensions, each followed by a group of statements that are developed for measuring the participants' level of self-appraisal in relation to these skills after being involved in an online digital tools-based program with the total number of 38 statements. Each statement has three response categories rating as follows: beginning, developing and mastering. Responses are given scores (weights) according the scale response categories as follows: beginning (1), developing (2) and mastering (3). Maximum score on the scale is 114. This is shown in table (9).

\section{1..

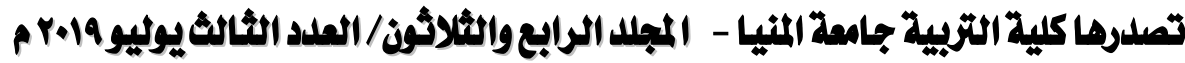




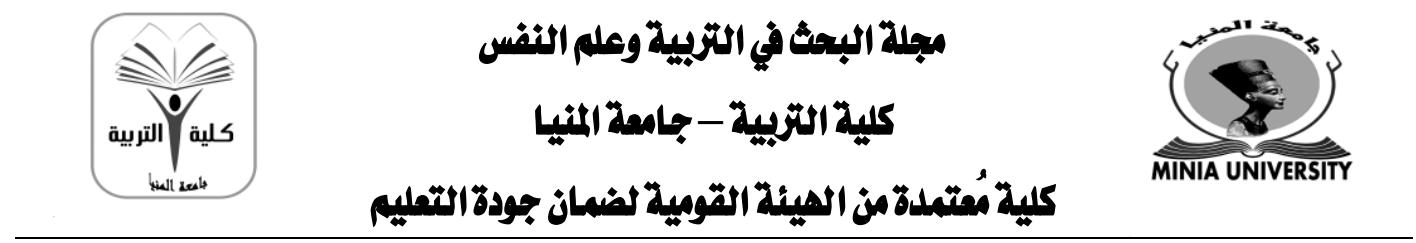

Table (9)

The Dimensions Self-Appraisal Scale

\begin{tabular}{ccc}
\hline No. & Dimensions of the scale & No. of items \\
\hline 1 & General professional skills & 14 \\
2 & Instructional delivery & 12 \\
3 & Language teaching skills & 12
\end{tabular}

Total number of items

38

Total score 114

Instructions of the scale. They are written in English. They are easy to understand. They include information about the purpose of the scale, its dimensions, the distribution of the scores on the points of the scale and the way of recording the answer.

Piloting the scale. Piloting the scale was done with a group of forty (40) male and female EFL pre-service teachers (juniors) enrolled at the Faculty of Education, Minia University in the academic year 2018/2019. Those participants were excluded later on from the intervention. Time taken by each participant was recorded, divided by the whole number of participants who took the scale and was found to be 30 minutes. Thus, the allotted time for using the scale was 30 minutes.

\section{Validity of the scale.}

1- The face validity of the scale. It was determined by submitting it to a jury of 5 TEFL experts to judge its validity according to the following criteria: linguistic stating of statements, relatedness of the statements to the skills of self-appraisal of language teaching performance and suitability of the statements to the subjects. The suggestions and recommendations of the jury members were taken into consideration and the scale was revised to reach its final form.

2- Pearson correlation. It was used to determine the internal consistency of the scale. The same piloting sample (40 EFL junior students) took the scale. The internal consistency of each statement was calculated. The internal consistency of the individual statements of the dimensions of the scale was calculated as shown in table (10). The correlation between the three dimensions of the

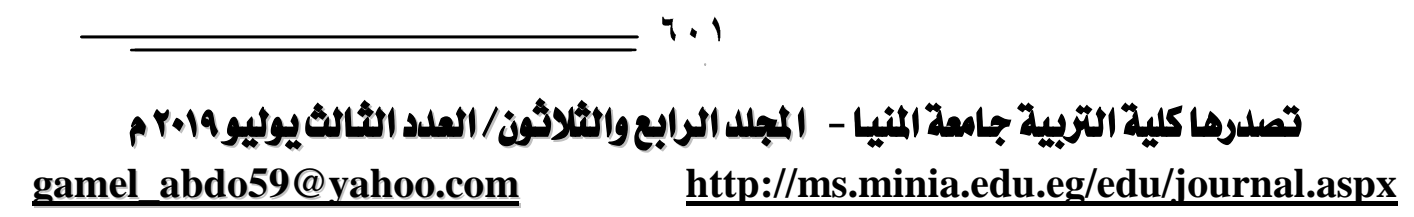



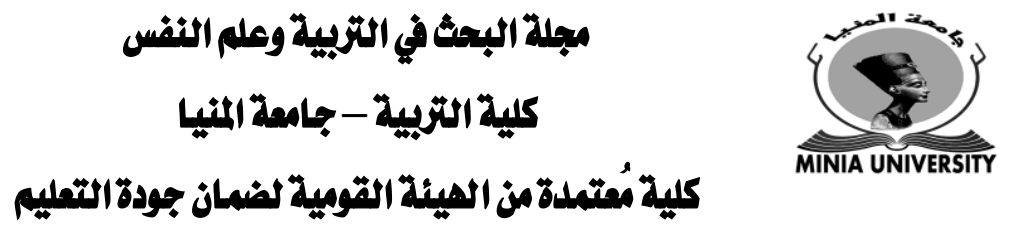

scale and the total scale was determined as shown in table (11). The values of the correlation coefficient, ranged from (0.313:

$0.913)$, are considered acceptable.

Table (10)

The Internal Consistency of the Scale of Self-appraisal

\begin{tabular}{|c|c|c|c|c|c|}
\hline Item no. & $\begin{array}{c}\text { Internal } \\
\text { consistency }\end{array}$ & Item no. & $\begin{array}{c}\text { Internal } \\
\text { consistency }\end{array}$ & Item no. & $\begin{array}{c}\text { Internal } \\
\text { consistency }\end{array}$ \\
\hline A1 & $.786 * *$ & A14 & $.484 * *$ & C1 & $.749 * *$ \\
\hline A2 & $.723 * *$ & B1 & $.714 * *$ & $\mathrm{C} 2$ & $.650 * *$ \\
\hline A3 & $.728 * *$ & B2 & $.504 * *$ & C3 & $.451 * *$ \\
\hline A4 & $.890 * *$ & B3 & $.680 * *$ & $\mathrm{C} 4$ & $.626^{* * *}$ \\
\hline A5 & $.913 * *$ & B4 & $.536 * *$ & $\mathrm{C} 5$ & $.846^{* *}$ \\
\hline A6 & $.518 * *$ & B5 & $.815^{* *}$ & C6 & $.614^{* *} *$ \\
\hline A7 & $.313^{*}$ & B6 & $.680 * *$ & C7 & $.795 * *$ \\
\hline A8 & $.471 * *$ & B7 & $.670 * *$ & $\mathrm{C} 8$ & $.846^{* *}$ \\
\hline A9 & $.729 * *$ & B8 & $.375^{*}$ & C9 & $.846^{* *}$ \\
\hline A10 & $.557 * *$ & B9 & $.899 * *$ & $\mathrm{C} 10$ & $.846^{* *}$ \\
\hline A11 & $.414 * *$ & B10 & $.744 * *$ & C11 & $.592 * *$ \\
\hline A12 & $.833 * *$ & B11 & $.461 * *$ & C12 & $.539 * *$ \\
\hline A13 & $.426 * *$ & B12 & $.465^{* * *}$ & - & - \\
\hline
\end{tabular}

Note. **. Correlation is significant at the 0.01 level (2-tailed).

Note. *. Correlation is significant at the 0.05 level (2-tailed).

Table (11)

The Correlation Between Each Dimension and The Total Scale

\begin{tabular}{cc}
\hline Dimensions & Internal consistency \\
\hline General professional skills & $.863^{* *}$ \\
Instructional delivery & $.881^{* *}$ \\
Language teaching skills & $.785^{* *}$ \\
\hline
\end{tabular}

Note. ${ }^{* *}$. Correlation is significant at the 0.01 level (2-tailed).

Reliability of the scale. Establishing the reliability of the scale was done during piloting. The same piloting sample (40 EFL junior students) took the scale. The reliability coefficient of the scale was determined using:

1- Alpha Cronbach ( $\alpha$ ) coefficient. It is (0.938). It is considered acceptable as shown in table (12)

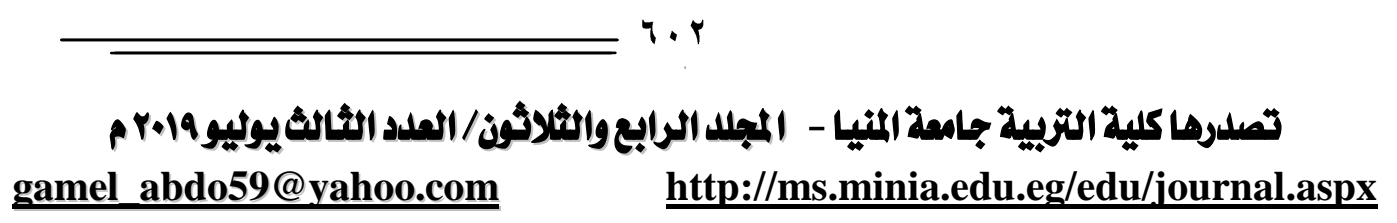




\begin{tabular}{|c|c|c|c|c|c|}
\hline \multicolumn{6}{|c|}{$\begin{array}{l}\text { Table (12) } \\
\text { The Cronbach Alpha's Reliability coefficient of the scale }\end{array}$} \\
\hline Dimensions & Means & Variance & $\begin{array}{c}\text { Standard } \\
\text { Deviation }\end{array}$ & $\begin{array}{l}\text { No. of } \\
\text { items }\end{array}$ & Alpha \\
\hline $\begin{array}{l}\text { General professional } \\
\text { skills }\end{array}$ & 16.53 & 11.230 & 3.351 & 14 & 0.895 \\
\hline Instructional delivery & 13.68 & 7.199 & 2.683 & 12 & 0.857 \\
\hline Language teaching skills & 13.33 & 7.097 & 2.664 & 12 & 0.900 \\
\hline Total of dimensions & 43.53 & 53.999 & 7.348 & 38 & 0.938 \\
\hline
\end{tabular}

Note. ${ }^{*}$. Alpha is significant at the 0.05 level (2-tailed).

2- The split-half method. Guttman split-half Coefficient of the scale is 0.704. It is considered acceptable as shown in table (13)

Table (13)

The Split-half Reliability coefficient of a scale of self-appraisal

\begin{tabular}{cccccc}
\hline $\begin{array}{c}\text { The scale of } \\
\text { self-appraisal }\end{array}$ & Means & Variance & $\begin{array}{c}\text { Standard } \\
\text { Deviation }\end{array}$ & $\begin{array}{c}\text { No. of } \\
\text { items }\end{array}$ & $\begin{array}{c}\text { Guttman } \\
\text { split-half } \\
\text { coefficient }\end{array}$ \\
\hline Part 1 & 22.38 & 20.446 & 4.522 & $19 \mathrm{a}$ & \\
Part 2 & 21.15 & 14.387 & 3.793 & $19 \mathrm{~b}$ & 0.710 \\
Both Parts & 43.53 & 53.999 & 7.348 & 38 & \\
\hline
\end{tabular}

Note. ${ }^{*}$ Correlation is significant at the 0.05 level (2-tailed).

Cohen et al. (2007:530) point out that the reliability coefficients are considered reliable if they range from 0.50 to 0.90 . Thus, the reliability coefficients of the scale are considered within the acceptable range.

\section{The material}

a- The material (the training program) consists of 4 units. The first unit (the introductory one) introduces the different types of visual tools, their benefits, sources and the visual literacy standards VLCs). The second and third units tackle visualizing the different aspects of language teaching; objectives, vocabulary, grammar, questioning and the four language skills. The last unit addresses the analysis of the different digitalized visuals used inside the classroom.

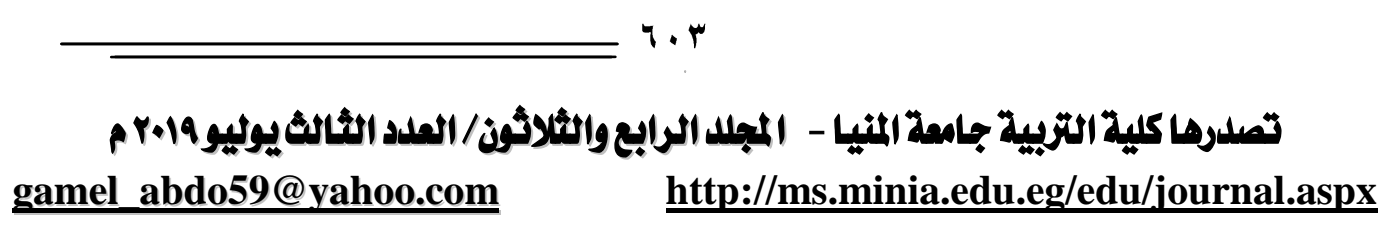




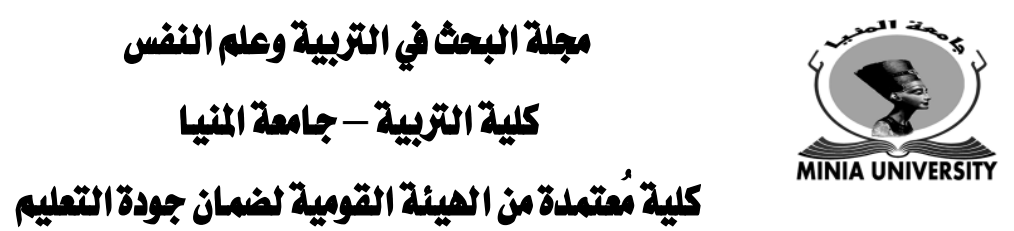

b- The construction of the training program has gone through the following steps: reviewing the literature related to the domain of visual literacy and self-evaluation, stating the general and the specific objectives of each lesson, preparing the content, submitting the program to 5 TEFL jury members to be judged according to the following criteria; statement of items, academic verification of the content, appropriateness of the method and the techniques used for the content and the participants of the study and applicability of the program.

\section{Instructional design of the study}

1- A questionnaire of self-identification was designed and applied by the researcher to be informed about the background knowledge that EFL junior students hold in relation to online leaning/teaching experiences as well as self-evaluation.

2-Pre-testing the participants of both the treatment and nontreatment groups, $(\mathrm{N}=80)$, using the inventory of visual literacy and the scale of self-appraisal before the intervention to ensure their homogeneity at the entry level.

c- The treatment intervention. The intervention of the treatment group has gone through the following stages:

1- Setting-up a closed group Facebook. This platform was intended to be used by the researcher for uploading course materials. Additionally, the student-teachers used it for exchanging questions and answers, sharing ideas and uploading personal artefacts and exchanging comments for better work enhancement.

2- Each aspect of teaching was presented and discussed well then, the suitable online digital resources were suggested. Modelling of the presented resources was carefully and explicitly performed. Then the student-teachers were asked to start performing their own visuals.

3- The student-teachers were instructed first to select videos, images, ready-made info-graphs. Step by step they started to $7 \cdot \varepsilon$

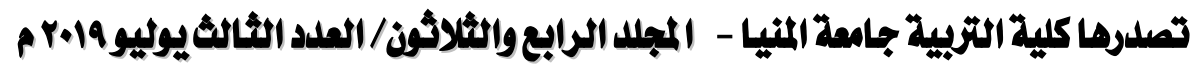
gamel_abdo59@yahoo.com

http://ms.minia.edu.eg/edu/journal.aspx 

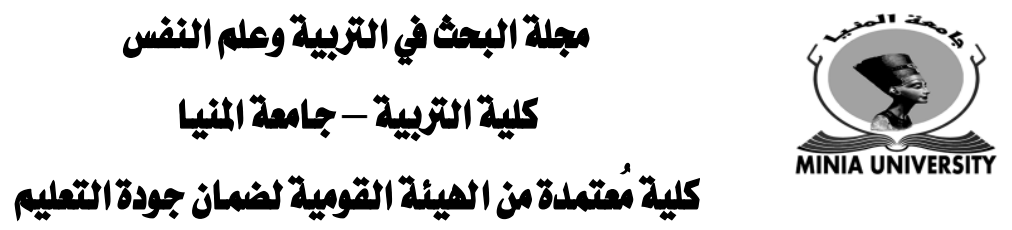

create their own visuals (e.g. diagrams, charts, etc.).

4- The student-teachers were left freely to work in groups or individually. Towards the end of the course, most of them showed great interest to work alone while others, especially with low ICT background, preferred to keep working in groups.

5- At the end of each meeting, student-teachers were asked to fill in different forms of self-evaluation tools directed towards assessing their abilities in teaching to reflect on the points of strength and consider these points that needed improvement.

6- After three sessions, student-teachers were accustomed to apply the presented material, search for extra resources, select or design personal visuals and upload to the face book group to receive comments for any modification needed for having better visual product.

d- The control treatment. Participants in the non-treatment group received instruction on the Micro teaching course using the regular way with no online-digital tools intervention.

e- Post-testing the participants of both the treatment and nontreatment groups, $(\mathrm{N}=80)$, using the inventory of visual literacy and the scale of self-appraisal after the intervention to compare the results with the pre-testing results.

The instructor. The researcher taught the treatment group only using the online-digital tools based-program by herself while the nontreatment group was instructed by another lecturer from the Faculty of Education using the regular procedures according to the rules of the institution.

The researcher served as a facilitator to guide the participants as they engaged in selecting, designing and interpreting visuals. The instructor's tasks mainly included uploading course materials, discussing with the participants the difficulties they encountered and providing suggestions to solve the problems.

Rather than using traditional resources for teaching, the researcher used authentic and updated materials, videos and visuals

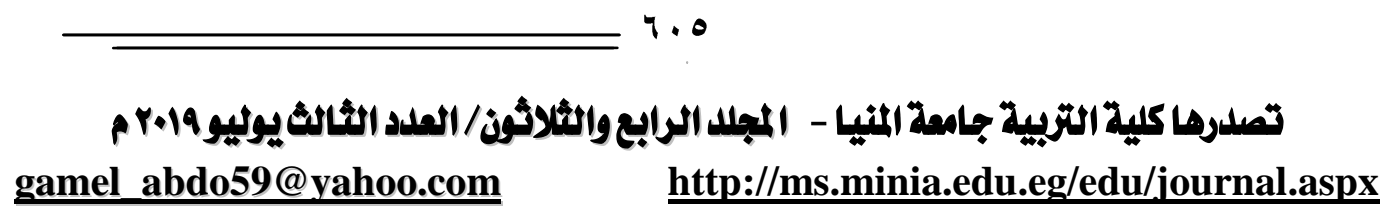



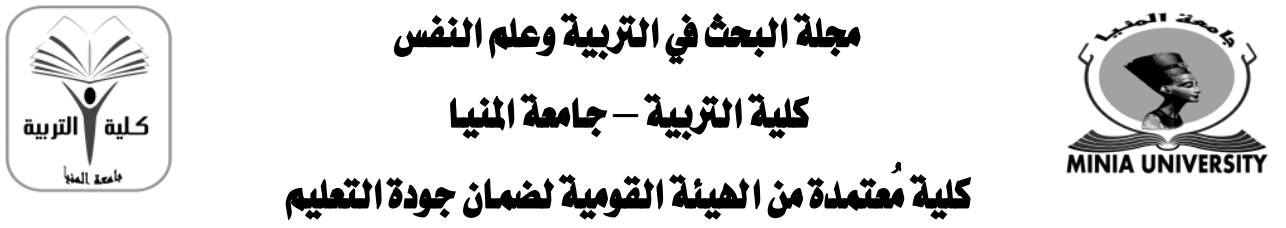

that participants found meaningful, interesting and relevant to their teaching context.

The researcher had to monitor participants' interaction and provide timely intervention. She had to take part in participants' discussion, comment on the uploaded materials and respond to questions online or in class to help keep the student-teachers' active spirit, creativity and enthusiasm.

\section{Findings \\ Hypothesis 1}

The first hypothesis of the study predicted that there was a statistically significant difference (favoring the treatment group) between mean values obtained by the participants of the treatment and the non-treatment groups on the post- performance of the inventory of visual literacy. Statistical analysis of the obtained data showed that the treatment group achieved a higher degree of improvement than the non-treatment group on the inventory of visual literacy as t-value (36.487) is significant at (0.05) level and beyond. Thus, the first hypothesis is confirmed. Table (14) below shows the data obtained to test this hypothesis.

Table (14)

Means, Standard Deviation, $t$ value, $\eta 2$ and effect size on the post-performance of both the experimental and control group of the inventory of visual literacy .

\begin{tabular}{|c|c|c|c|c|c|c|c|c|c|}
\hline $\begin{array}{c}\text { Aspects of } \\
\text { comparison }\end{array}$ & Group & No. & $\begin{array}{c}\text { Mea } \\
\mathbf{n} \\
\end{array}$ & Std. (SD) & t-value & df & $\begin{array}{c}\text { Sig. } \\
\text { (2-tailed) }\end{array}$ & $\eta 2$ & $\begin{array}{c}\text { Effect } \\
\text { size }\end{array}$ \\
\hline $\begin{array}{l}\text { The nature of } \\
\text { the visual }\end{array}$ & $\begin{array}{c}\text { Post- } \\
\text { treatment. }\end{array}$ & 40 & 16.28 & 2.364 & 18.712 & 71.250 & 0.000 & 0.8178 & Large \\
\hline materials needed & $\begin{array}{l}\text { Post-non- } \\
\text { treatment. }\end{array}$ & 40 & 7.63 & 1.720 & & & & & \\
\hline $\begin{array}{l}\text { The sources and } \\
\text { types of the }\end{array}$ & $\begin{array}{c}\text { Post- } \\
\text { treatment.. }\end{array}$ & 40 & 14.10 & 1.707 & 28.592 & 55.905 & 0.000 & 0.9129 & Large \\
\hline visual materials & $\begin{array}{l}\text { Post-non- } \\
\text { treatment. }\end{array}$ & 40 & 5.55 & 0.815 & & & & & \\
\hline $\begin{array}{l}\text { The effective } \\
\text { search and }\end{array}$ & $\begin{array}{c}\text { Post- } \\
\text { treatment.. }\end{array}$ & 40 & 22.25 & 2.880 & 25.894 & 57.558 & 0.000 & 0.8958 & Large \\
\hline $\begin{array}{l}\text { organization for } \\
\text { visuals }\end{array}$ & $\begin{array}{l}\text { Post-non- } \\
\text { treatment. }\end{array}$ & 40 & 9.05 & 1.449 & & & & & \\
\hline
\end{tabular}

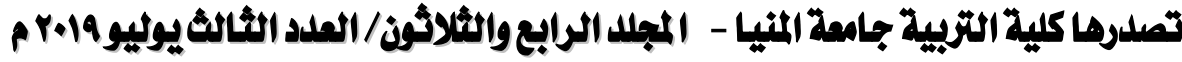

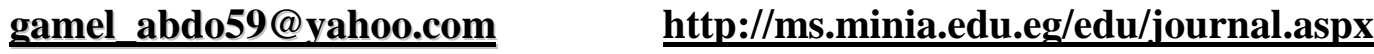




\begin{tabular}{|c|c|c|c|c|c|c|c|c|c|}
\hline $\begin{array}{l}\text { Aspects of } \\
\text { comparison }\end{array}$ & Group & No. & $\begin{array}{c}\text { Mea } \\
\mathbf{n}\end{array}$ & Std. (SD) & t-value & df & $\begin{array}{c}\text { Sig. } \\
\text { (2-tailed) }\end{array}$ & $\eta 2$ & $\begin{array}{c}\text { Effect } \\
\text { size }\end{array}$ \\
\hline \multirow[t]{2}{*}{$\begin{array}{l}\text { The creation and } \\
\text { design of visuals }\end{array}$} & $\begin{array}{c}\text { Post- } \\
\text { treatment.. }\end{array}$ & 40 & 10.55 & 2.136 & 27.780 & 52.341 & 0.000 & 0.9082 & Large \\
\hline & $\begin{array}{l}\text { Post-non- } \\
\text { treatment.. }\end{array}$ & 40 & 6.38 & 0.897 & & & & & \\
\hline \multirow{4}{*}{$\begin{array}{c}\text { The } \\
\text { interpretation } \\
\text { and analysis of } \\
\text { visuals } \\
\text { Total of } \\
\text { dimensions }\end{array}$} & $\begin{array}{l}\text { Post- } \\
\text { treatment.. }\end{array}$ & 40 & 18.75 & 2.145 & 25.453 & 70.205 & 0.000 & 0.8925 & Large \\
\hline & $\begin{array}{l}\text { Post-non- } \\
\text { treatment. }\end{array}$ & 40 & 8.18 & 1.517 & & & & & \\
\hline & $\begin{array}{c}\text { Post- } \\
\text { treatment.. }\end{array}$ & 40 & 87.93 & 8.097 & 36.487 & 53.936 & 0.000 & 0.9447 & Large \\
\hline & $\begin{array}{l}\text { Post-non- } \\
\text { treatment. }\end{array}$ & 40 & 36.78 & 3.613 & & & & & \\
\hline
\end{tabular}

Note. *. significant at the 0.05 level (2-tailed).

To ensure the effectiveness of the online-digital tools-based program in improving participants' visual literacy, eta-squared formula statistics $(\eta 2)$ was used. Cohen et al. (2007:522) pointed out that when eta-squared value $=0.01$, the effect is considered weak, when it = 0.06 , the effect is considered medium and when it $=0.14$ the effect is large. As shown in table (14) eta-squared value $(\eta 2)$ equals (0.9447) which is considered large. Thus, the online-digital tools-based program is considered with high effect in improving EFL junior students' visual literacy.

Additionally, the comparison of the values obtained by the participants of both the treatment and non-treatment groups in the prepost performance on the inventory of visual literacy revealed that the treatment group outperformed the non-treatment group as t-value (36.546) is significant at 0.05 level and beyond. Eta- squared value ( $\eta 2)$ equals $(0.9716)$ which is considered large. This is shown in table(15).

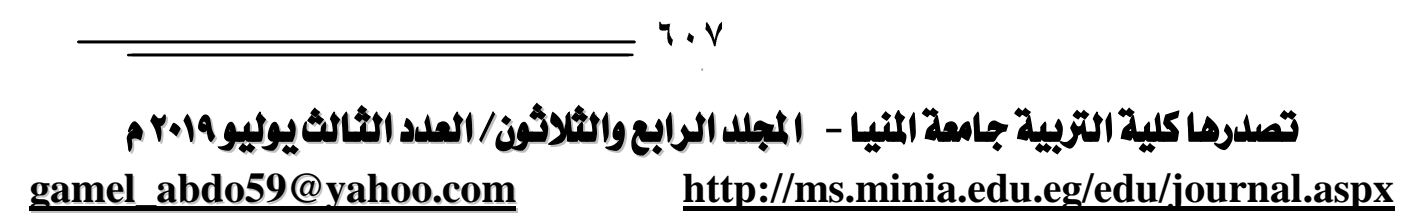



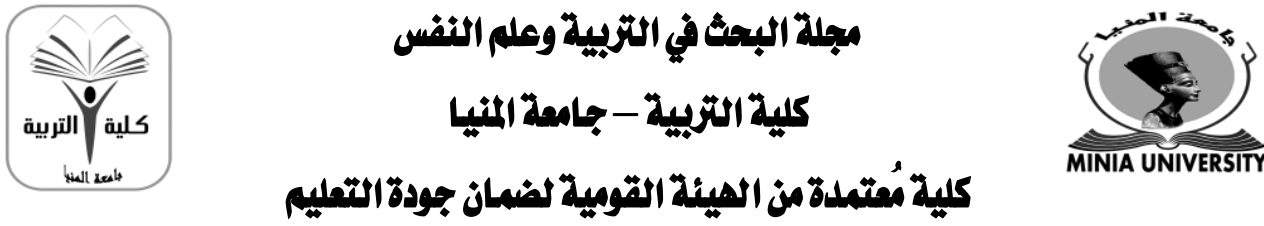

Table (15)

Means, Standard Deviation, $t$ value, $\eta 2$ and effect size between mean scores of the experimental and the control group on the Pre-Post of the visual literacy skills inventory. $\mathrm{N}=40$

\begin{tabular}{|c|c|c|c|c|c|c|c|c|c|}
\hline $\begin{array}{c}\text { Aspects of } \\
\text { comparison }\end{array}$ & Group & $\begin{array}{c}\text { Mea } \\
\mathbf{n}\end{array}$ & $\begin{array}{l}\text { Mean } \\
\text { diff. }\end{array}$ & $\begin{array}{c}\text { Stand. } \\
\text { Dev. }\end{array}$ & t-value & df & $\begin{array}{l}\text { Sig. (2- } \\
\text { tailed) }\end{array}$ & $\eta 2$ & $\begin{array}{l}\text { Effect } \\
\text { size }\end{array}$ \\
\hline \multirow{4}{*}{$\begin{array}{c}\text { The nature of } \\
\text { the visual } \\
\text { materials } \\
\text { needed }\end{array}$} & $\begin{array}{c}\text { Pre- } \\
\text { treatment. }\end{array}$ & 7.43 & -8.850 & 1.880 & -17.585 & 39 & " 0.000 & 0.8880 & Large \\
\hline & $\begin{array}{l}\text { Post- } \\
\text { treatment. }\end{array}$ & 16.28 & & 2.364 & & & & & \\
\hline & $\begin{array}{l}\text { Pre-non-. } \\
\text { Treatment }\end{array}$ & 7.58 & -0.050 & 1.838 & -0.138 & 39 & 0.891 & 0.0005 & Small \\
\hline & $\begin{array}{l}\text { Post-non- } \\
\text { treatment. }\end{array}$ & 7.63 & & 1.720 & & & & & \\
\hline \multirow{4}{*}{$\begin{array}{l}\text { The sources } \\
\text { and types of } \\
\text { the visual } \\
\text { materials }\end{array}$} & $\begin{array}{c}\text { Pre- } \\
\text { treatment }\end{array}$ & 5.50 & -8.600 & 0.906 & -27.057 & 39 & 0.000 & 0.9494 & Large \\
\hline & $\begin{array}{c}\text { Post- } \\
\text { treatment }\end{array}$ & 14.10 & & 1.707 & & & & & \\
\hline & $\begin{array}{l}\text { Pre-non- } \\
\text { treatment. }\end{array}$ & 5.63 & 0.075 & 1.170 & 0.363 & 39 & 0.719 & 0.0034 & Small \\
\hline & $\begin{array}{l}\text { Post-non- } \\
\text { treatment. }\end{array}$ & 5.55 & & 0.815 & & & & & \\
\hline \multirow{4}{*}{$\begin{array}{l}\text { The effective } \\
\text { search and } \\
\text { organization } \\
\text { for visuals }\end{array}$} & $\begin{array}{c}\text { Pre- } \\
\text { treatment. }\end{array}$ & 9.13 & -13.125 & 1.572 & -24.160 & 39 & 0.000 & 0.9374 & Large \\
\hline & $\begin{array}{c}\text { Post- } \\
\text { treatment. }\end{array}$ & 22.25 & & 2.880 & & & & & \\
\hline & $\begin{array}{l}\text { Pre-non- } \\
\text { treatment. }\end{array}$ & 8.98 & -0.075 & 1.915 & -0.200 & 39 & 0.842 & 0.0010 & Small \\
\hline & $\begin{array}{l}\text { Post-non- } \\
\text { treatment. }\end{array}$ & 9.05 & & 1.449 & & & & & \\
\hline \multirow{4}{*}{$\begin{array}{l}\text { The creation } \\
\text { and design of } \\
\text { visuals }\end{array}$} & $\begin{array}{c}\text { Pre- } \\
\text { treatment. }\end{array}$ & 6.58 & -9.975 & 1.010 & -32.064 & 39 & 0.000 & 0.9635 & Large \\
\hline & $\begin{array}{c}\text { Post- } \\
\text { treatment. }\end{array}$ & 16.55 & & 2.136 & & & & & \\
\hline & $\begin{array}{l}\text { Pre-non- } \\
\text { treatment. }\end{array}$ & 6.43 & 0.050 & 0.931 & 0.233 & 39 & 0.817 & 0.0014 & Small \\
\hline & $\begin{array}{l}\text { Post-non- } \\
\text { treatment. }\end{array}$ & 6.38 & & 0.897 & & & & & \\
\hline $\begin{array}{l}\text { The } \\
\text { interpretation }\end{array}$ & $\begin{array}{c}\text { Pre- } \\
\text { treatment. }\end{array}$ & 8.25 & -10.500 & 1.565 & -23.864 & 39 & 0.000 & 0.9359 & Large \\
\hline
\end{tabular}

$7 \cdot 1$ 


\begin{tabular}{|c|c|c|c|c|c|c|c|c|c|}
\hline $\begin{array}{c}\text { Aspects of } \\
\text { comparison }\end{array}$ & Group & $\begin{array}{c}\text { Mea } \\
\text { n }\end{array}$ & $\begin{array}{c}\text { Mean } \\
\text { diff. }\end{array}$ & $\begin{array}{c}\text { Stand. } \\
\text { Dev. }\end{array}$ & t-value & df & $\begin{array}{l}\begin{array}{l}\text { Sig. }(2- \\
\text { tailed })\end{array} \\
\end{array}$ & $\eta 2$ & $\begin{array}{c}\text { Effect } \\
\text { size }\end{array}$ \\
\hline \multirow{3}{*}{$\begin{array}{l}\text { and analysis } \\
\text { of visuals }\end{array}$} & Post- & 18.75 & & 2.145 & & & & & \\
\hline & $\begin{array}{l}\text { Pre-non- } \\
\text { treatment. }\end{array}$ & 8.23 & 0.050 & 1.847 & 0.134 & 39 & 0.894 & 0.0005 & Small \\
\hline & $\begin{array}{l}\text { Post-non-. } \\
\text { Treatment }\end{array}$ & 8.18 & & 1.517 & & & & & \\
\hline \multirow{4}{*}{$\begin{array}{c}\text { Total of } \\
\text { dimensions }\end{array}$} & Pre- & 36.88 & -51.050 & 3.763 & -36.546 & 39 & 0.000 & 0.9716 & Large \\
\hline & Post- & 87.93 & & 8.097 & & & & & \\
\hline & $\begin{array}{l}\text { Pre-non- } \\
\text { treatment. }\end{array}$ & 36.83 & 0.050 & 5.088 & 0.059 & 39 & 0.953 & 0.0001 & Small \\
\hline & $\begin{array}{l}\text { Post-non- } \\
\text { treatment. }\end{array}$ & 36.78 & & 3.613 & & & & & \\
\hline
\end{tabular}

Note. *. significant at the 0.05 level (2-tailed).

\section{Hypothesis 2}

The second hypothesis of the study predicted that there was a statistically significant difference (favoring the treatment group) between mean values obtained by the participants of the treatment and the non-treatment groups on the post- performance of the scale of selfappraisal. Statistical analysis of the obtained data showed that the treatment group achieved a higher degree of improvement than the non-treatment group on the scale of self-appraisal as t-value (50.820) is significant at (0.05) level and beyond. Thus, the second hypothesis is confirmed. Table (16) below shows the data obtained to test this hypothesis. 


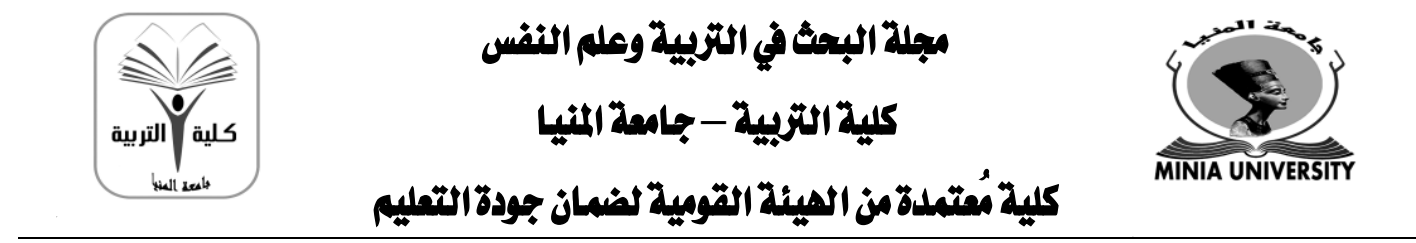

Table (16)

Means, Standard Deviation, $t$ value, $\eta 2$ and effect size on the post-performance of both the experimental and control group of the self-appraisal Scale.

\begin{tabular}{|c|c|c|c|c|c|c|c|c|c|}
\hline $\begin{array}{l}\text { Aspects of } \\
\text { comparison }\end{array}$ & Group & No. & Mean & $\begin{array}{l}\text { Std. } \\
\text { SD }\end{array}$ & t-value & df & $\begin{array}{c}\text { Sig. } \\
(2- \\
\text { tailed) }\end{array}$ & $\eta 2$ & $\begin{array}{c}\text { Effect } \\
\text { size }\end{array}$ \\
\hline \multirow{2}{*}{$\begin{array}{c}\text { General } \\
\text { Professional skills }\end{array}$} & Post- & 40 & 34.73 & 3.202 & 28.509 & 72.491 & 0.000 & 0.9124 & Large \\
\hline & $\begin{array}{l}\text { treatment. } \\
\text { Post-non- } \\
\text { treatment. }\end{array}$ & 40 & 16.65 & 2.413 & & & & & \\
\hline \multirow[t]{2}{*}{$\begin{array}{l}\text { Instructional } \\
\text { delivery }\end{array}$} & $\begin{array}{c}\text { Post- } \\
\text { treatment. }\end{array}$ & 40 & 30.40 & 3.144 & 29.260 & 58.443 & 0.000 & 0.9165 & Large \\
\hline & $\begin{array}{l}\text { Post-non- } \\
\text { treatment. }\end{array}$ & 40 & 14.03 & 1.625 & & & & & \\
\hline \multirow[t]{2}{*}{$\begin{array}{c}\text { Language } \\
\text { teaching skills }\end{array}$} & $\begin{array}{c}\text { Post- } \\
\text { treatment. }\end{array}$ & 40 & 32.48 & 1.987 & 42.022 & 78 & 0.000 & 0.9577 & Large \\
\hline & $\begin{array}{l}\text { Post-non- } \\
\text { treatment. }\end{array}$ & 40 & 13.65 & 2.020 & & & & & \\
\hline \multirow[t]{2}{*}{$\begin{array}{c}\text { Total of } \\
\text { dimensions }\end{array}$} & $\begin{array}{c}\text { Post- } \\
\text { treatment. }\end{array}$ & 40 & 97.60 & 5.715 & 50.820 & 63.107 & 0.000 & 0.9707 & Large \\
\hline & $\begin{array}{l}\text { Post-non- } \\
\text { treatment. }\end{array}$ & 40 & 44.33 & 3.362 & & & & & \\
\hline
\end{tabular}

Note. *. significant at the 0.05 level (2-tailed).

To ensure the effectiveness of the online digital tools-based program in improving participants' self-appraisal, eta-squared formula statistics ( 2 2) was used. Cohen et al. (2007:522) pointed out that when eta-squared value $=0.01$, the effect is considered weak, when it $=0.06$, the effect is considered medium and when it $=0.14$ the effect is large. As shown in table (15) eta-squared value( $\eta 2)$ equals (0.9707) which is considered large. Thus, the online digital tools-based program is considered with high effect in improving EFL junior students' self-appraisal.

Additionally, the comparison of the values obtained by the participants of both the treatment and non-treatment groups in the prepost performance on the scale of self-appraisal revealed that the treatment group outperformed the non-treatment group as t-value (48.577) is significant at 0.05 level and beyond. Eta- squared value ( $\eta 2$ ) equals (0.9837) which is considered large. This is shown in table (17).

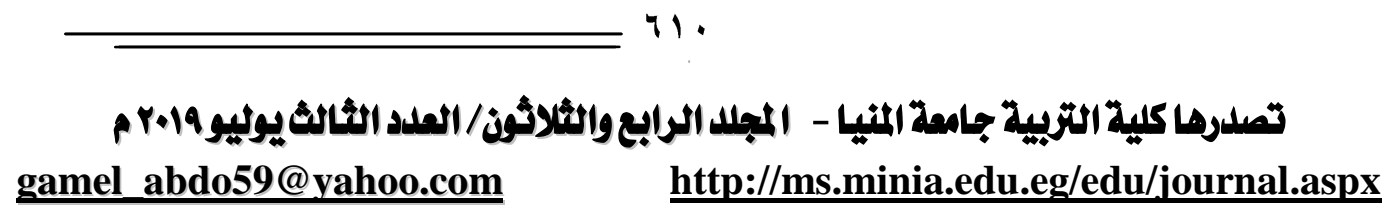




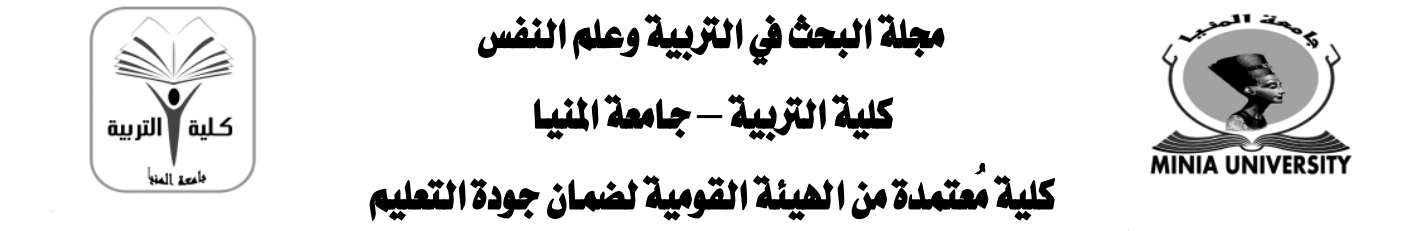

Table (17)

Means, Standard Deviation, $t$ value, $\eta 2$ and effect size between mean scores of the experimental and the control group on the Pre-Post of the scale of self- appraisal. N=40

\begin{tabular}{|c|c|c|c|c|c|c|c|c|c|}
\hline $\begin{array}{c}\text { Aspects of } \\
\text { comparison }\end{array}$ & Group & Mean & $\begin{array}{c}\text { Mean } \\
\text { diff. }\end{array}$ & $\begin{array}{l}\text { Stand. } \\
\text { Dev. }\end{array}$ & t-value & df & $\begin{array}{l}\text { Sig. (2- } \\
\text { tailed) }\end{array}$ & $\eta 2$ & $\begin{array}{c}\text { Effect } \\
\text { size }\end{array}$ \\
\hline \multirow{4}{*}{$\begin{array}{c}\text { General } \\
\text { Professional } \\
\text { skills }\end{array}$} & $\begin{array}{c}\text { Pre- } \\
\text { treatment }\end{array}$ & 16.48 & -18.250 & 2.679 & -28.026 & 39 & 0.000 & 0.9527 & Large \\
\hline & $\begin{array}{c}\cdot \\
\text { Post- } \\
\text { treatmen. }\end{array}$ & 34.73 & & 3.202 & & & & & \\
\hline & $\begin{array}{l}\text { Pre-non- } \\
\text { treatmen. }\end{array}$ & 16.60 & -0.050 & 2.458 & -0.703 & 39 & 0.486 & 0.0125 & Small \\
\hline & $\begin{array}{l}\text { Post-non- } \\
\text { treatmen. }\end{array}$ & 16.65 & & 2.413 & & & & & \\
\hline \multirow[t]{4}{*}{$\begin{array}{c}\text { Instructional } \\
\text { delivery }\end{array}$} & $\begin{array}{c}\text { Pre- } \\
\text { treatmen. }\end{array}$ & 14.05 & -16.350 & 2.160 & -30.008 & 39 & 0.000 & 0.9585 & Large \\
\hline & $\begin{array}{c}\text { Post- } \\
\text { treatmen. }\end{array}$ & 30.40 & & 3.144 & & & & & \\
\hline & $\begin{array}{l}\text { Pre-non- } \\
\text { treatmen. }\end{array}$ & 14.00 & -0.025 & 1.710 & -0.274 & 39 & 0.785 & 0.0019 & Small \\
\hline & $\begin{array}{l}\text { Post-non- } \\
\text { treatmen. }\end{array}$ & 14.03 & & 1.625 & & & & & \\
\hline \multirow[t]{4}{*}{$\begin{array}{c}\text { Language } \\
\text { teaching skills }\end{array}$} & $\begin{array}{c}\text { Pre- } \\
\text { treatmen. }\end{array}$ & 13.70 & -18.775 & 1.772 & -41.136 & 39 & 0.000 & 0.9775 & Large \\
\hline & $\begin{array}{c}\text { Post- } \\
\text { treatmen. }\end{array}$ & 32.48 & & 1.987 & & & & & \\
\hline & $\begin{array}{l}\text { Pre-non- } \\
\text { treatmen. }\end{array}$ & 13.58 & -0.075 & 2.241 & -0.684 & 39 & 0.498 & 0.0119 & Small \\
\hline & $\begin{array}{l}\text { Post-non- } \\
\text { treatmen. }\end{array}$ & 13.65 & & 2.020 & & & & & \\
\hline \multirow[t]{4}{*}{$\begin{array}{c}\text { Total of } \\
\text { dimensions }\end{array}$} & $\begin{array}{c}\text { Pre- } \\
\text { treatmen. }\end{array}$ & 44.23 & -53.375 & 4.515 & -48.577 & 39 & 0.000 & 0.9837 & Large \\
\hline & $\begin{array}{l}\text { Post- } \\
\text { treatmen. }\end{array}$ & 97.60 & & 5.715 & & & & & \\
\hline & $\begin{array}{l}\text { Pre-non- } \\
\text { treatmen. }\end{array}$ & 44.18 & -0.150 & 3.580 & -1.233 & 39 & 0.225 & 0.0375 & Small \\
\hline & $\begin{array}{l}\text { Post-non- } \\
\text { treatmen. }\end{array}$ & 44.33 & & 3.362 & & & & & \\
\hline
\end{tabular}

Note. ${ }^{*}$. significant at the 0.05 level (2-tailed). 


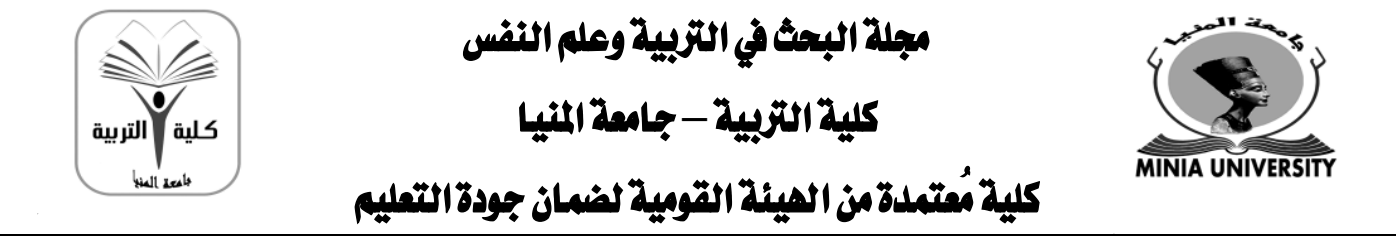

\section{Discussion of Results}

The inherent features of the study on the basis of the students' reflections

The participants have welcomed at the early beginning of the intervention the idea of having a virtual platform (Closed Face book Group) for uploading materials, sharing ideas, clarifying misconceptions and exchanging ideas especially with the involvement of their instructor. The smooth transition towards the use of visuals in the teaching context through ready- made charts and images was acceptable.

The real challenging point has started when the participants were instructed to access different online resources (e.g. Lucid chart, Fluent U, Flicker, Pearltrees, etc.) to start designing their own resources. However, using videos for illustrating tasks as well as modelling the designing processes by the instructor herself facilitated the tasks. The student-teachers have demonstrated the great help they received after watching videos. Some of them have used to upload more illustrative materials to the group Face book for sharing help and benefit.

The constant dialogue through face-to-face meetings/ sessions or through using the virtual group as well as the continuous opportunities for reflection have ensured that the design framework reflected the pedagogical principles underlying the course. Moreover, the different means of self-assessment tasks presented in each lesson have led to their self-confidence in their abilities to create, design, interpret and use creatively visual materials.

After showing great talent in selecting and designing different forms of visuals (e.g. structures diagrams, word images, Frayer models for practice,.etc.), they started to negotiate the ideal ways of handling such visuals. The presentation of the analysis of the different visual tools was of great help. The student-teachers have accustomed to select, modify or even designing visuals weakly.

The student-teachers have changed their work style from group

ir

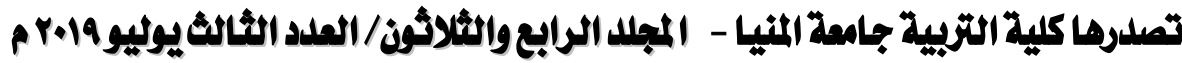

gamel_abdo59@yahoo.com

http://ms.minia.edu.eg/edu/journal.aspx 

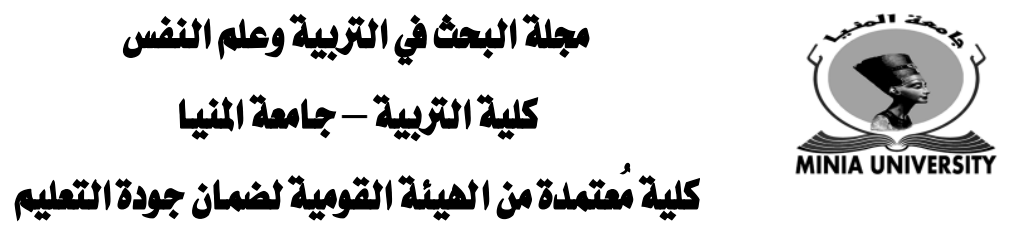

work to pairs till they become confident enough to work individually. All the materials selected or designed were uploaded systematically to the closed Face book group for peers' and instructor's comments. The student- teachers showed great responses towards modification, altering colors, considering the size of the letters or even changing the visual itself. They welcomed others' comments and commented on their peers as they felt responsible for spreading awareness and sharing knowledge.

The relation of the present study's results to the results of other conducted studies

Results of studies that coincide with those obtained by the present study. The findings of the present study corresponded with Dyre et. al. (2015) and Shabiralyani et al. (2015) in assuring the positive impact of the technical devices on both teachers' and learners' informative systems. Likewise, the present study was consistent with Thamarana (2017) in emphasizing the role of internet-based technology in suppling learners with authentic and realistic experience to practice language learning and teaching. Concerning visuals, the results of the present study were similar to the results of Ulloa Salazar and Díaz Larenas (2018) and Zakareya and Alahmad (2019) in documenting the learners' positive performance change whenever images or videos were shown. These studies have assured the impact of using visuals to consolidate the knowledge and skills that student teachers received in a theoretical way through watching videos of model teachers, using pedagogically sound visual tools and being able to create their own context-specific visual resources(e.g. mind maps, graphs, diagrams, charts, animated images, trailers, etc.).

Results of studies that show the limitations of internet supplies. Some studies have demonstrated the idea that online courses are not ideal for everyone due to the need of appropriate learning styles and basic competencies (El Mansour \& Mupinga, 2007). Similar studies also have pinpointed the lack of ICT resources, lack of access to the right kinds of technology, inadequate ICT pedagogical training and

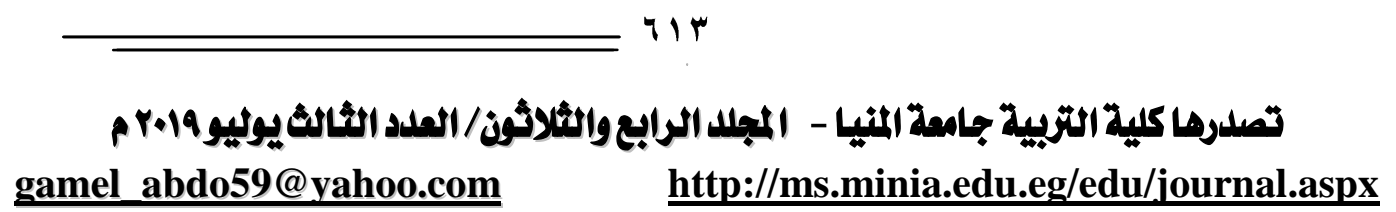



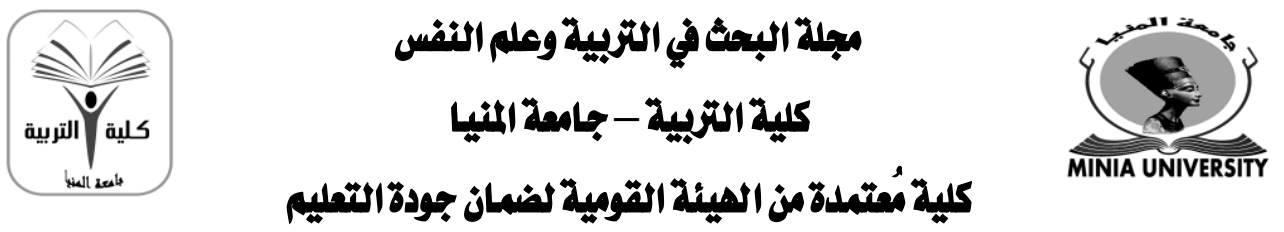

insufficient administrative support as basic limitations for using online digital devices for teaching/learning purposes (Riehemann \& Jucks, 2017 ; Chinyamurindi \& Dlaza,2018).

\section{Conclusion}

The integration of online digital visuals in the preparation of student-teachers has provided them with opportunities for collaboration and reflection. All the students-teachers were enabled to access a variety of resources and share their perspectives and visual artefacts. They were also critically engaged in collaborative work and discussion that led to enhance their learning and enable them to realign their professional teaching beliefs and practices.

\section{Implications}

1. Teacher leaders and other educators knowledgeable about instruction and closest to the classroom should be active participants in the professional learning strategies currently in use.

2. The importance of using social networks for professional and classroom learning.

3. The critical need for using digital-age communication and collaboration tools to promote teaching performance, enhance learning and extend cultural understanding and global awareness.

4. Technological tools should support teaching, not dominate it.

5. The use of a well-considered pedagogical framework in creating an innovative online learning experience would lead to rich learning environments

6. Teachers' self-evaluation data can be used as a basis for analyzing and improving their instruction, though this data must be validated with the evaluation of experts or peers for better professional improvement.

7. Instructors and course designers need to leverage online technology, in a pedagogical way, to further enhance students' cognition and knowledge retention.

8. Integrating visual literacy into the academic programs requires collaboration and shared implementation strategies across the various levels. 

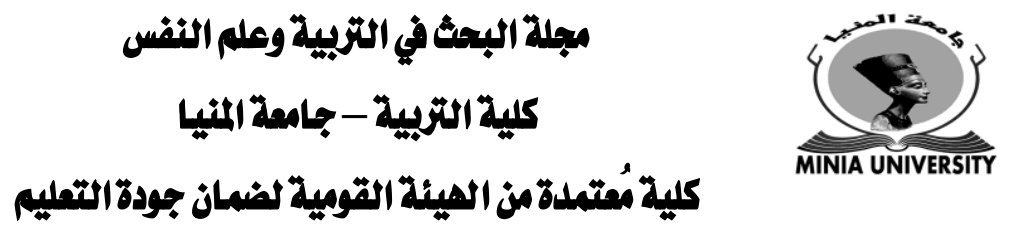

9. Information communication technologies have great potential for knowledge dissemination, effective learning and the development of more efficient educational services.

10. Teachers' attitudes are positive towards the use of educational technology, then they can easily provide useful insights about the adoption and integration of ICT into teaching and learning processes.

11. Student teachers tend to be more sensitive to the use of digital technologies when they are accustomed to its use.

\section{Recommendations}

1. Self-assessment skills must be made integral to teacher-preparation programs.

2. Teacher educators should include a range of assessment methods within their own coursework to provide professional development opportunities for pre-service students and in-service teachers to form a deeper understanding of the utility of different assessment approaches.

3. The impact of the personalization of technology.

4. Educators should be exposed to modern use of teaching resources such as audio and visual aids, computers, photographic materials such as film strips slides, photographs, flat pictures and internet to keep updated.

5. A certain level of computer literacy should be required for employment as an English teacher.

\section{Suggestions for further research}

1. The use of technology to facilitate a variety of effective assessment and evaluation strategies.

2. The relationship between EFL teachers' assessment literacy and their teaching style.

3. The use of adaptive or assistive technologies, such as audio descriptions of visual materials or multimodal access to visual media, as accessible strategies for visual materials.

4. This study may be replicated with a larger and more diverse sample of EFL students from different governates in Egypt. 


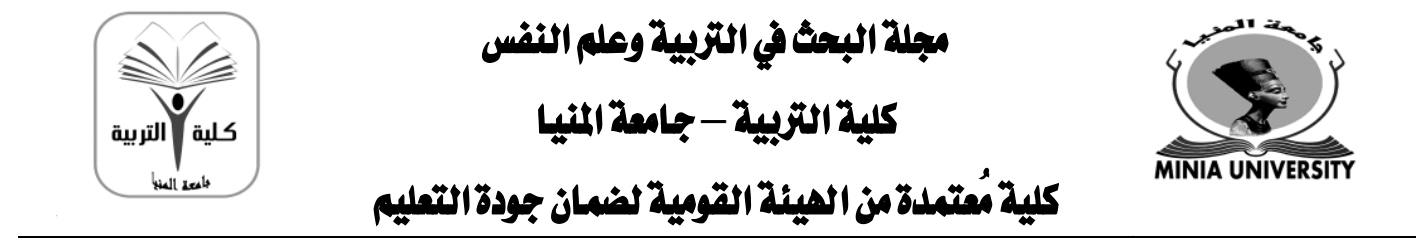

\section{Reierences}

Ashraf, H., \& Zolfaghari, S. (2018). EFL Teachers' Assessment Literacy and Their Reflective Teaching. International Journal of Instruction, 11(1), 425-436.

Benali, M., Kaddouri, M., \& Azzimani, T. (2018). Digital competence of Moroccan teachers of English. International Journal of Education and Development using ICT, 14(2).

Borg, S., \& Edmett, A. (2018). Developing a self-assessment tool for English language teachers. Language Teaching Research, 1-25.

Calvert, K. (2014). Facilitating the Quest: A Case Study of Three Technologies in an EAPP Writing Classroom. CATESOL Journal, 25(1), 106-117.

Çam, E., \& Kiyici, M. (2017). Perceptions of Prospective Teachers on Digital Literacy. Malaysian Online Journal of Educational Technology, 5(4), 29-44.

Chinyamurindi, W., \& Dlaza, Z. (2018). Can you teach an old dog new tricks? An exploratory study into how a sample of lecturers develop digital literacies as part of their career development. Reading \& Writing, 9(1), 1-8.

Cohen, L., Manion, L., \& Morrison, K. (2007). Research methods in education.

Cote, T., \& Milliner, B. (2018). A survey of EFL teachers' digital literacy: a report from a Japanese university. Teaching English with Technology, 18(4), 71-89.

Donnchaidh, S. (2017). Teaching visual literacy in the classroom. Retrieved from https://www.literacyideas.com/teaching-visualtexts-in-the-classroom

Durriyah, T. , \& Zuhdi, M. (2018). Digital Literacy with EFL Student Teachers: Exploring Indonesian Student Teachers' Initial Perception about Integrating Digital Technologies into a Teaching Unit. International Journal of Education and Literacy Studies, 6(3), 53-60.

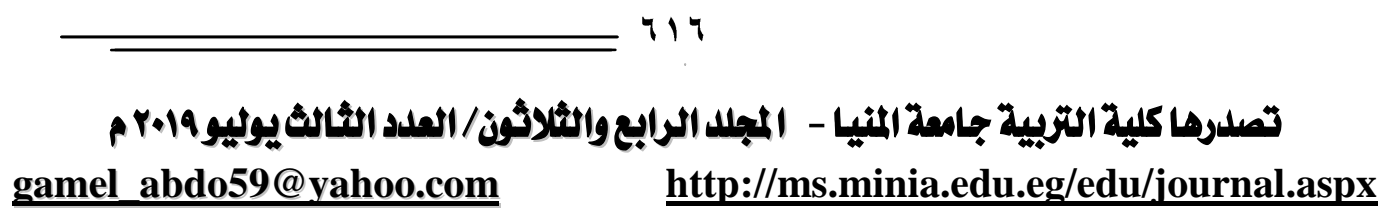



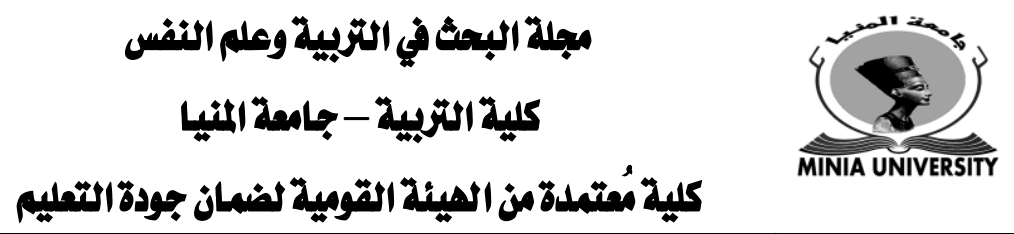

Dyer, T., Larson, E., Steele, J., \& Holbeck, R. (2015). Integrating Technology into the Online Classroom through Collaboration to Increase Student Motivation. Journal of Instructional Research, 4, 126-133.

El Mansour, B., \& Mupinga, D. (2007). Students' positive and negative experiences in hybrid and online classes. College student journal, 41(1), 242-248.

Gareis, C., \& Grant, L. (2015). Assessment Literacy for Teacher Candidates: A Focused Approach. Teacher Educators' Journal, 2015, 4-21.

Hattwig, D., Burgess, J., Bussert, K., \& Medaille, A. (2011). ACRL visual literacy competency standards for higher education. Association of College and Research Libraries.

Hilliker, E. (2018). 5 things English learners need from classroom teachers. Retrieved from https://www.teachingchannel.org/blog/2018/06/25/5-thingsells-need

Jansen, C., \& van der Merwe, P. (2015). Teaching practice in the 21st century: Emerging trends, challenges and opportunities. Universal Journal of Educational Research, 3(3), 190-199.

Jenkins, R. (2015). Integrating digital literacy into English language instruction: Companion learning resource. Washington, DC: US Department of Education, Office of Career, Technical, and Adult Education.

Keddie, J. (n.d.). Visual literacy in ELT. Retrieved January 18, 2019 from https://www.teachingenglish.org.uk/article/jamie-keddievisual-literacy-elt-0

Krajka, J. (2006). Teaching listening comprehension with web-based video. The Teacher, 5(39), 8-16.

Magana, s. (2017). Teacher self-assessment guide for T3 framework. Retrieved from http://resources.corwin.com/sites/default/files/Table_6.2.pdf $71 \mathrm{~V}$ 

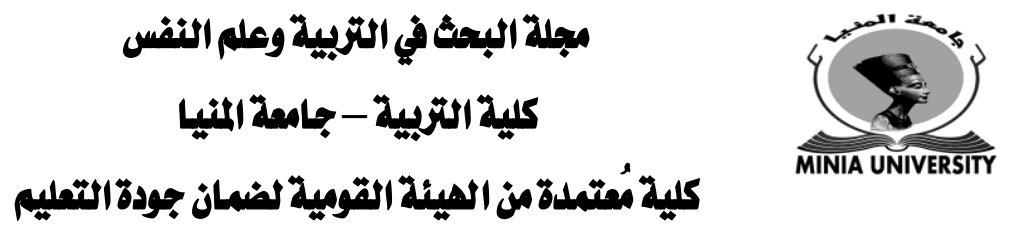

Office of Educational technology. (2014). Professional learning strategies self-assessment tool. Retrieved from https://tech.ed.gov/wpcontent/uploads/2014/11/Section-3-

Strategies-Self-Assessment-FINAL.pdf

Office of Educational technology. (n.d.). Future ready schools: empowering educators through professional learning toolkit. Retrieved February 20, 2019 from https://tech.ed.gov/futureready/professional-learning/

Pinchot, J., \& Paullet, K. (2014). Different Keystrokes for Different Folks: Addressing Learning Styles in Online Education. Information Systems Education Journal, 12(2), 2937.

Pohio, L., \& Lee, M. (2012). Re-visualising innovative online learning spaces in an early childhood teacher education programme. Journal of Open, Flexible, and Distance Learning, 16(1), 99-107.

Prasojo, L., Mukminin, A., Habibi, A., Marzulina, L., Muhammad, S., \& Harto, K. (2018). Learning To Teach In A Digital Age: ICt Integration And EFL Student Teachers' teaching Practices. Teaching English with Technology, 18(3), 18-32.

Riehemann, J., \& Jucks, R. (2017). How Much Is Teaching and Learning in Higher Education Digitized? Insights from Teacher Education. International Journal of Higher Education, 6(3), 129-137.

Sailin, S. \& Mahmor, N. (2018). Improving Student Teachers' Digital Pedagogy through Meaningful Learning Activities. Malaysian Journal of Learning and Instruction, 15(2), 143-173.

Schwartz, M. (n.d.). Self-evaluation of Teaching. Retrieved March 5, 2019 from https://www.ryerson.ca/content/dam/lt/resources/handouts/Self Evaluation.pdf

Sevcikova, B. (2018). Online Open-Source Writing Aid as a Pedagogical Tool. English Language Teaching, 11(8), 126-142. 711

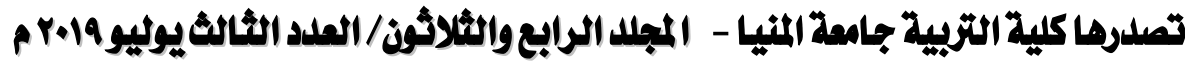
gamel_abdo59@yahoo.com

http://ms.minia.edu.eg/edu/journal.aspx 

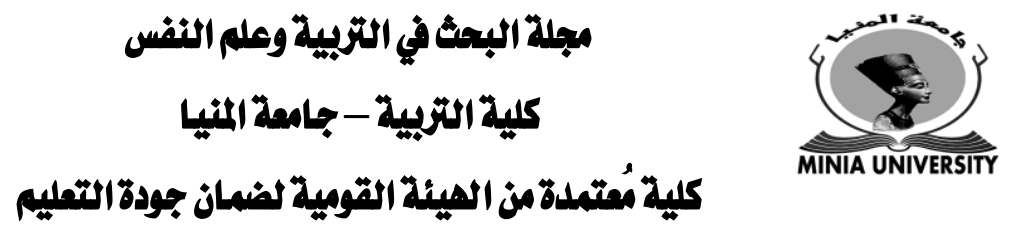

Shabiralyani, G., Hasan, K., Hamad, N., \& Iqbal, N. (2015). Impact of Visual Aids in Enhancing the Learning Process Case Research: District Dera Ghazi Khan. Journal of Education and Practice, 6(19), 226-234.

Spiller, D. (2012). Assessment matters: Self-assessment and peer assessment. New Zealand: Teaching Development, University of Waikato.

Stabler-Havener, M. (2018). Defining, Conceptualizing, Problematizing, and Assessing Language Teacher Assessment Literacy. Working Papers in Applied Linguistics \& TESOL, 18(1), 1-22.

Thamarana, S. (2017). Role of Strategies and Resources for Teaching Listening Skills Online, 4.

Ulloa Salazar, G., \& Díaz Larenas, C. (2018). Using an Audiovisual Materials-Based Teaching Strategy to Improve EFL Young Learners' Understanding of Instructions. How, 25(2), 91-112.

Zakareya, S., \& Alahmad, S. (2019). Inverted Teaching for Improving the Teaching Performance of EFL Student Teachers at Jubail College of Education, 12(4).

Zeglen, E., \& Rosendale, J. (2018). Increasing Online Information Retention: Analyzing the Effects of visual hints and feedback in educational games. Journal of Open, Flexible, and Distance Learning, 22(1), 22-33. 